\title{
Spatially explicit statistical modeling of random and systematic land cover transitions in the main grassland plain of Nech Sar National Park, Ethiopia
}

\author{
Kiros Tsegay Deribew (D)
}

\begin{abstract}
The main grassland plain of Nech Sar National Park (NSNP) is a federally managed protected area in Ethiopia designated to protect endemic and endangered species. However, like other national parks in Ethiopia, the park has experienced significant land cover change over the past few decades. Indeed, the livelihoods of local populations in such developing countries are entirely dependent upon natural resources and, as a result, both direct and indirect anthropogenic pressures have been placed on natural parks. While previous research has looked at land cover change in the region, these studies have not been spatially explicit and, as a result, knowledge gaps in identifying systematic transitions continue to exist. This study seeks to quantify the spatial extent and land cover change trends in NSNP, identify the strong signal transitions, and identify and quantify the location of determinants of change. To this end, the author classifies panchromatic aerial photographs in 1986, multispectral SPOT imagery in 2005, and Sentinel imagery in 2019. The spatial extent and trends of land cover change analysis between these time periods were conducted. The strong signal transitions were systematically identified and quantified. Then, the basic driving forces of the change were identified. The locations of these transitions were also identified and quantified using the spatially explicit statistical model. The analysis revealed that over the past three decades (19862019), nearly 52\% of the study area experienced clear landscape change, out of which the net change and swap change attributed to $39 \%$ and $13 \%$, respectively. The conversion of woody vegetation to grassland $(\sim 5 \%)$, subsequently grassland-to-open-overgrazed land (28.26\%), and restoration of woody vegetation (0.76\%) and grassland (0.72\%) from riverine forest and open-overgrazed land, respectively, were found to be the fully systematic transitions whereas the rest transitions were recorded either partly systematic or random transitions. The location of these most systematic land cover transitions identified through the spatially explicit statistical modeling showed drivers due to biophysical conditions, accessibility, and urban/market expansions, coupled with successive government policies for biodiversity management, geo-politics, demographic, and socioeconomic factors. These findings provide important insights into biodiversity loss, land degradation, and ecosystem disruption. Therefore, the model for predicted probability generally suggests a $0.75 \mathrm{~km}$ and $0.72 \mathrm{~km}$ buffers which are likely to protect forest and grassland from conversion to grassland and open-overgrazed land, respectively.
\end{abstract}

Keywords: Agro-pastoralist, Deforestation, Degradation, Overgrazing, Pastoralists 


\section{Introduction}

The livelihoods of human population in most of developing countries are almost entirely relied on natural resources. This resulted in conversion/modification of land use/land cover (LULC) though it varies from one area to other areas. Many studies highlighted that tropical areas have been hosted a significant LULC conversion than other regions over the last two decades (Lambin et al. 2003; FAO 2010; Ouedraogo et al. 2016). Large scale of deforestation was found to be one of the main drivers of LULC change (Zeleke and Hurni 2001; Deribew and Dalacho 2019). Owing to deforestation and land degradation, the problem has been very severe for the last three decades in Sub-Saharan Africa countries (Lohnert 2017), particularly in populous country like highlands of Ethiopia where annual rate of deforestation has been ahead of afforestation/reforestation since the 1950s (Deribew and Dalacho 2019). This resulted in ecosystem disruptions mainly in the lowland scenery areas where high dependence on rain-fed subsistence farming has contributed to transform the land and natural resources.

In the rift valley of Ethiopia, over the last three decades, the ecosystems have been subjected to a serious of disturbances such as drought (Biazin and Sterk 2013), civil unrest (Belay et al. 2014), large human and livestock population pressure (Temesgen and Bikila 2018), and resettlement policy (Belay et al. 2014; Arjjumend et al. 2018). More recently, LULC conversion due to human and livestock population pressure is a common experience in and outside protected areas in Ethiopia (Belay et al. 2014; Zerga 2015; Fetene et al. 2016). Despite the efforts in establishments of protected areas mainly national parks which were aimed at conserving the environment and socioeconomic benefits, the areas have been facing serious challenges from governmental policies and demographicrelated issues (Belay et al. 2014; Fetene et al. 2016). Such phenomenon could have far-reaching implications for wildlife conservation and natural resource management. Studies indicated that in the national parks of Ethiopia, substantial expansion of grazing lands, human settlements, farmlands, and infrastructures have been observed over the past four decades (Belay et al. 2014; Wolde Yohannes et al. 2017; Arjjumend et al. 2018). Belay et al. (2014) reported that scattered bush land was drastically reduced by 29.4\% from 1972 to 2006 in Awash National Park. Policy and park border demarcation issues were identified as key drivers for LULC change before the mid-1990s and livestock grazing after 1995. However, Wolde Yohannes et al. (2017) reported a 29\% of agricultural land expansion mainly at the expense of woodlands observed between 1973 and 2016 in Abijata Shalla National Park of Ethiopia. Woodland destructions for cropland and domestic energy were found to be the major drivers. The same experience has also been observed where farmland had greatly expanded by more than half at the expense of forest during 1985 and 2015 in Bale Mountain Eco-region of Ethiopia (Hailemariam et al. 2016).

Moreover, rural-rural migration (pastoralists), villagization programs (grouping of scattered communities), and innovation of agro-pastoralists (mixed farming) along the national parks put additional pressure on LULC change (Belay et al. 2014; Fetene et al. 2016). Following the frequent drought inhabitants has also been settled legally and illegally along the agro-pastoralist areas (Wolde Yohannes et al. 2017). This has also been marked a surge of pastoralists to dispersal areas (acting as wildlife migratory corridors) around the national parks (Syombua 2013). Due to increasing demand of local communities, national parks located in lowland areas of the central rift valley Ethiopia are highly exposed to LULC change (Hailemariam et al. 2016). Those protected areas proximate to water bodies, settlements, infrastructures, forage, forest edge, and plain areas are more vulnerable to habitat degradation and biodiversity depletion than other side areas (Belay et al. 2014). Such phenomena have also been observed in semi-arid rangeland of Tsavo west national park in southern Kenya, where wildlife habitat destruction occurred due to agricultural expansion and human population growth (Syombua 2013). This confirmed that agricultural expansion, human settlement expansion, and frequent local clan conflicts were escalating mammoth scale of deforestation that finally leads to habitat destruction in the national parks (Andabo and Gamo 2015). Most of these remotely sensed satellite imageries and GIS-based land cover change studies were traditional, which have focused primarily on how much, where, and what type of land cover change has happened. Rarely have the analyses considered whether the observed land cover transitions appear to have happened due to a clearly systematic processes or due to an apparently random process, according to the analyzed report in the transition matrices.

Some literature, therefore, suggested that class-to-class transitions can be either random or systematic process of changes (Pontius 2004; Alo and Pontius Jr 2008; Ouedraogo et al. 2016). In the statistical sense of analysis of land cover transition matrices, a land cover category is said to gain randomly from others if the gains are in proportion to the availability of those losing categories. Correspondingly, the land cover category is said to lose randomly to others if such losses are in proportion to the size of other gaining categories. Any large positive or negative deviation from those proportions refers to a systematic landscape change. Studies such as Braimoh (2006) and Teferi et al. (2013) highlighted that the detection of statistically random and systematic land cover transitions enables land use researchers and planners to emphasis on the strong signals of change, examine the 
possible drivers using quantitative and ancillary qualitative data, and therefore pledge measures to avoid or minimize the undesirable impacts of land change. In this regard, using this advanced land change mechanism Braimoh (2006) has used this scientific statistical technique, in Northern Ghana, to report that the expansion of cropland systematically targets grassland for takeover, though cropland systematically avoids taking over woodland. Likewise the observed pattern, forest conversion to cropland was found to be abrupt change, i.e., the random process of change, whereas conversion of grassland to cropland was regular, i.e., systematic process of change, in Jedeb watershed, upper Blue Nile of Ethiopia (Teferi et al. 2013). Thus, it is vivid that several authors describe the transitions as a process of change that transforms the landscape system; for systematic transitions, these transitions are driven by stable and gradual processes.

Therefore, a mere conducting LULC change does not necessarily lead to improve understanding of the process of land cover conversion which researchers and policy makers would seek to establish conservation and management strategies for land resources (Teferi et al. 2013; Mondal et al. 2014; Ouedraogo et al. 2016). Understanding the fundamental process of land transitions requires detection of dominant systematic land cover transitions (Pontius 2004; Braimoh 2006; Alo and Pontius Jr 2008) and spatially explicit modeling (Veldkamp and Lambin 2001; Verburg and Veldkamp 2001; Verburg et al. 2004; Teferi et al. 2013; Mondal et al. 2014). Therefore, the spatially explicit modeling of land cover change has been carried out to identify the proximate causes and determinants of the strong signal transitions. The model was found to be very helpful to link land cover transitions with explanatory variables, thereby predict the location of strong signal transitions, if they are combined with spatially explicit data (Teferi et al. 2013; Ouedraogo et al. 2016). However, there is still very little historical data available to help understand the location of drivers of disturbance on the main grassland plain of the Nech Sar National Park (NSNP). Hence, understanding the fundamental processes of land cover transitions requires detections of strong signal transitions to avoid habitat disturbance.

The main grassland plain of Nech Sar National Park (NSNP) is a federally managed protected area in Ethiopia designated to protect endemic and endangered species. However, like other national parks in Ethiopia, the park has experienced significant land cover change over the past few decades. Indeed, the livelihoods of local populations in such developing countries are dependent upon natural resources and, as a result, both direct and indirect anthropogenic pressures have been placed on natural parks. While previous research has looked at land cover change in the region, these studies have not been spatially explicit and, as a result, knowledge gaps in identifying systematic transitions continue to exist. This study seeks to quantify the spatial extent and land cover change trends in NSNP, identify the strong signal transitions, and identify and quantify the location of determinants of change. In order to do this, the author classifies panchromatic aerial photographs in 1986, multispectral SPOT imagery in 2005, and Sentinel imagery in 2019. Therefore, understanding the strong signal transitions and the location of these determinants in the main grassland plain of the park could be a contribution to the ecosystem services. The findings of this study contribute to the literatures in the areas of forestry, landscape ecology, biodiversity, land use planning, environmental planning, ecosystem, and society to investigate signals of systematic transitions and possible drivers of transitions thereby to offer site-specific wildlife conservation and anticipatory measures.

\section{Data and methods}

\section{Study area}

NSNP is one of the federally managed protected areas of Ethiopia which was established in 1974 to protect the endemic and endangered species such as Swayne's hartebeest (Alcelaphus buselaphus swaynei) and Grant's zebra (Equus quagga) (Jacobs and Schroeder 1997).

The study area, the main savannah grassland plain of NSNP, lies between latitudes $550^{\prime}$ to $60^{\prime} \mathrm{N}$ and longitudes $3737^{\prime}$ to $3743^{\prime} 51^{\prime \prime} \mathrm{E}$ and covers a total area of $10,483 \mathrm{ha}$. It is situated $510 \mathrm{~km}$ south of Addis Ababa with an altitude range of $960-1469 \mathrm{~m}$ above sea level (Fig. 1). It is situated in the lowland areas of the central rift valley of Ethiopia. It is characterized by extended plain and small hilly areas. It combines dry savannah grasslands, lakes, bushes and shrubs mixed with grasses, woodlands, and riverine forest. The natural and encroached woody vegetation mixed with dominant bush and shrub lands of the study area are found in the northern tip of the park, along the eastern margin of Lake Chamo. The riparian (riverine) forests are found along the Sermele river banks along the eastern part of the park. The central part of the park of the study area is dominated by savanna "white grass" (Chrysopogon plumulosus). The woody vegetation, grassland, and riverine forest are the most threatened habitat types in the study area.

The study area is experienced hot semi-arid tropical climate with mean annual rainfall and temperature ranging from 600 to $800 \mathrm{~mm}$ and 19 to $31^{\circ} \mathrm{C}$, respectively. The precipitation is further characterized by a typical bimodal rainfall pattern with highest fall in April/May and August/September (NMA 2013).

The study area is surrounded by more than 10 ethnic groups (mainly pastoralists and agro-pastoralists) with about two million populations (Wolde Yohannes et al. 2018). The livelihoods of the inhabitants in the study 


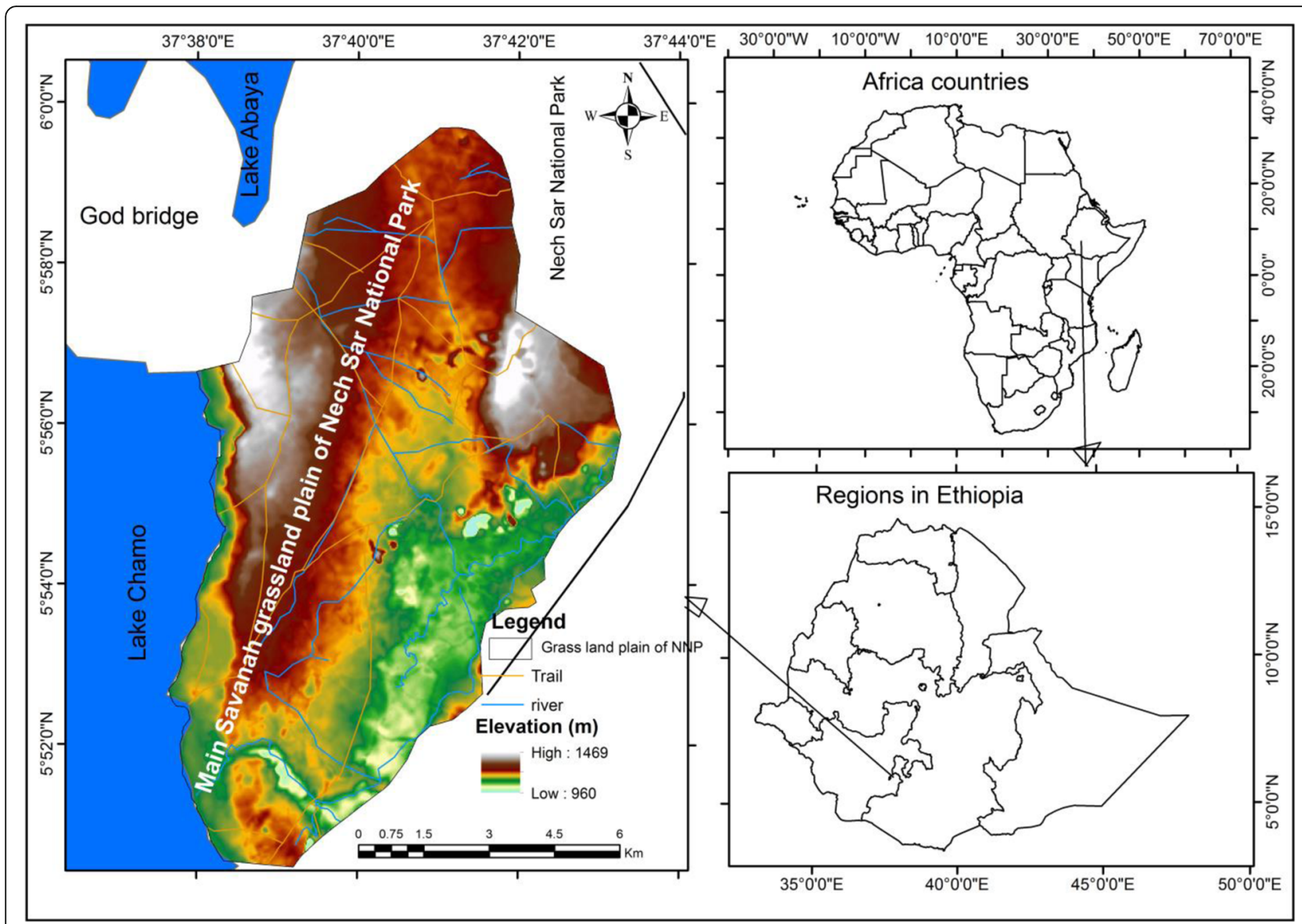

Fig. 1 Location and topography of the main grassland plain of NSNP

area are entirely dependent on natural resources found around and in the park. They are mainly engaged in movable rearing animals, agro-pastoralism, forestry, fishery, tourism, and trade. The Gujis (I and II) and Borena areas are the first largest producer of livestock mainly cattle, goat, and camel in the country. Consequently, this marked dry savanna grassland is adjudicated to carry massive livestocks beyond its carrying capacity which is finally converted into degradation. Such activities are another severe challenge in the area which leads the people to frequent war and conflict on park border demarcation. This further heightened rural-rural migration surge to national parks for settlement expansion. Moreover, shortage of land for pasture, cropland, and settlement areas outside the study area forced the communities to exploit the park.

This study focuses on the main grassland plain of the park's terrestrial habitats, and the portion of the park was selected due to its ecological significance. The area is ultimate for providing daily and seasonal forage and water resources, breading grounds, and mating opportunities that act as corridors for several thousands of herbivores, carnivores, omnivores, and birds species.

\section{Data sources and pre-processing}

In this study, to generate the LULC types, panchromatic aerial photographs of 1984 and 1986 at the scale of 1 : 50000 and multispectral SPOT image of 2005 at the spatial resolution of $10 \times 10 \mathrm{~m}$ were purchased from Geospatial Information Agency (GIA). Sentinel image dated 2019 at the spatial resolution of $10 \times 10 \mathrm{~m}$ was freely accessed from European Space Agency (ESA) used to produce the LULC type for 2019 (Table 1). All study periods were selected due to availability of the data.

Supportive data such as topographic map of the study area dated 1984 was purchased and used to check the geometric position of all data. To generate a slope and aspect as topographic variables, ASTER Global Digital Elevation Model (ASTER GDEM) was accessed through free of charge from US NASA. Similarly, stream networks were generated from DEM using SWAT model in ArcGIS spatial analyst tool. Common road/trails were digitized from IKONOS image.

All scenes of aerial photographs were scanned in A3 format with 600 dots per inch (dpi), and orthorectified image was made to Universal Transverse Mercator Projection (UTM Zone 37) in ERDAS imagine software. On 
Table 1 Descriptions of used aerial photographs and satellite images

\begin{tabular}{|c|c|c|c|}
\hline & 1986 & 2005 & 2019 \\
\hline Satellite (sensor) & Aerial photographs & SPOT-5 & Sentinel-2 \\
\hline Resolution (pixel spacing)/scale & 1:50000 (resampled to $10 \times 10 \mathrm{~m})$ & $10 \times 10(\mathrm{~m})$ & $10 \times 10(\mathrm{~m})$ \\
\hline Sources & GIA & GIA & ESA \\
\hline Path/row/contact numbers & ET 1: 55 10-14: 1006-1008;1100-1103; 1193-1195 & ---- & ----- \\
\hline Acquisition date & 01/19/1984/86 & $10 / 02 / 2005$ & 01/01/2019 \\
\hline
\end{tabular}

each scene of scanned contacts of aerial photographs, about four Ground Control Points (GCPs) were collected from bridges and river intersections, and the average root mean square error (RMSE) was 0.53. During this process, topographic map at the scale of 1:50000 was used as base map for geo-referencing the orthophoto of 1986 and the SPOT image of 2005 with a similar projection. Features were then identified visually on the basis of shape, size, and texture on the orthophotos (Teferi et al. 2013; Deribew and Dalacho 2019). Finally, to satisfy the result of this study, all data (vector and raster) collected from different sources were resampled to $10 \mathrm{~m}$ resolution for better convenience (Table 1).

\section{Development of image classification and accuracy assessment}

To identify the major LULC types, the land use classification scheme suggested by Jensen (1996) was considered. In addition, to better understand the context, field visit and information from local elders and experts were conducted. Thus, four major LULC types (woody/shrub vegetation, grassland, riverine/riparian forest, and openovergrazed land) were identified.

In this study, a total of 802 sample reference points from each study year were collected; of which 562 and 240 sample points were used for LULC classification and ground truth, respectively. For the references 1986, 2005, and 2019, points were collected from their respective historical Google Earth images. Aerial photograph of 1986 was resampled to $10 \mathrm{~m}$ resolution as SPOT image of 2005 and Sentinel image of 2019 experienced. To produce LULC types for the above images, object-based classification technique was employed.

To evaluate the degree of accuracy output, the classified LULC categories were compared to ground truth data (Lillesand et al. 2008). The notation OA is the overall accuracy in Eq. 1 which presents the number of sample points that were classified correctly. Equation 2 indicates the Kappa coefficient (Khat) to evaluate the actual and a chance agreement between classified data and referenced data, where $n$ is the total number of samples collected for ground truth. The diagonal values denoted by $X_{\mathrm{ii}}$ presented the numbers classified correctly.

$$
\begin{aligned}
\mathrm{OA} & =\frac{\Sigma \mathrm{X}_{i j}}{N} * 100 \\
\text { Khat } & =\frac{N \sum_{i=1}^{r} \mathrm{X}_{i j}-\sum_{i=1}^{r}\left(\mathrm{X}_{i+} * X_{+i}\right)}{N^{2}-\sum_{i=1}^{r}\left(\mathrm{X}_{i+} * X_{+i}\right)}
\end{aligned}
$$

\section{Spatial extent and trends of land use/land cover transitions}

Post classification change detection and cross-tabulation comparison matrices (Hung and Wu 2005; Yuan et al. 2005) were carried out for each span period. Analysis of LULC transition gain, loss, persistence, swap, total change, and net change were computed for all span study periods: 1986-2005, 2005-2019, and 1986-2019 (Ouedraogo et al. 2016). The contingency table of land cover transition matrices comprises rows that exhibit LULC categories of class $i$ at time $1\left(P_{i+}\right)$ and columns that exhibit LULC categories by class $j$ at time $2\left(P_{+j}\right)$. The gain row shows the proportion of the land cover types that experienced a gross gain of class $j$ between time periods whereas the losses column shows the proportion of the land cover types that experienced a gross loss of class $i$ between time periods (Table 3 ). The net changes, denoted by $D_{j}$, were calculated as the difference between gains and losses, and the values were indicated in absolute values (Eq. 3). However, net change underestimates the total change on the landscape since it fails to capture the "swap" (Teferi et al. 2013). Swap $\left(S_{j}\right)$ implies simultaneous gain and loss of a category on the landscape category. The amount of swap of land class $j, S_{j}$ was therefore computed (Eq. 4). If the net quantity change is zero (implying gain is equal to loss), then the swap location change is twice the gain or loss. Thus, the amount of swap of land class $j$ was computed as two times the minimum of gains and loss because to create a pair of grid cells that swap each grid cell that gains is paired with a gird cell that loses (Pontius 2004; Teferi et al. 2013). Equation 5 defines the total change $\left(C_{j}\right)$ for each landscape was computed as either the sum of the net change and the swap or the sum of the gain and loss.

Moreover, LULC vulnerability to transition called lossto-persistence ratio $\left(l_{p}\right)$ to evaluate the exposure of land cover transitions, and gain-to-persistence ratio $\left(g_{p}\right)$ to determine the gains of land cover transitions, and gain- 
to-loss $(\mathrm{g} / \mathrm{l})$ to examine the lucre and havoc of landscapes were computed. To estimate the annual rate of deforestation at different periods, the methods outlined in Puyravaud (2003) were considered (Eq. 6).

$$
\begin{aligned}
& \mathrm{D} j=\left|P_{+j}-P_{j+}\right| \\
& \mathrm{S} j=2 x \min \left(P_{j+}-P_{j j}, P_{+j}-P_{j j}\right) \\
& \left.\mathrm{C} j=D_{j}+S_{j}=P_{j+}+P_{+j}-2 P_{j j}\right) \\
& \mathrm{r}=\left[\left(\frac{100}{\Delta t}\right) * \ln \left(\frac{A_{2}}{A_{1}}\right)\right]
\end{aligned}
$$

where $n$ is the total number of classes. The proportions of landscape $P_{i+}$ and $P_{+j}$ that are occupied by class $i$ and $j$ in different time periods. $r$ is annual rate of LULC change, and $A_{1}$ and $\boldsymbol{A}_{2}$ are the area coverage of a land cover at $t_{1}$ and $t_{2}$.

\section{Detecting random and most systematic transitions}

Unlike traditional way and random of identification transitions, interpreting the transitions in relation to the size of categories is prominent to identify the strong signal (systematic) land cover transitions. Considering to the statistical principle of chi-square $\left(X^{2}\right)$, "random" landscape transition is occurred if a LULC class gains from other losing class or if the class loses to other class in proportion to the size of the those other gaining classes (Pontius 2004; Braimoh 2006; Alo and Pontius Jr 2008; Teferi et al. 2013; Ouedraogo et al. 2016). In this study, therefore, once the amount of gains, losses, and swaps of each category was designed, the expected gains and losses were derived for the period 1986-2019. The expected gains and losses due to randomly distributed processes are then compared to the observed gains and losses in order to differentiate between apparently random and systematic transitions, in terms of gains and losses. Hence, to identify the strong signal transitions methods developed by Pontius (2004) were applied. Equations 7 and 8 define the expected random gains $\left(G_{i j}\right)$ and losses $\left(L_{i j}\right)$ which were used to determine the systematic transitions. In other words, $D_{i j}$ is the difference between the observed and expected transitions under a random process of gains $\left(P_{i j}-G_{i j}\right)$ or loss $\left(P_{i j}-L_{i j}\right)$ Table 3 .

$$
\begin{aligned}
\mathrm{G}_{\mathrm{ij}} & =\left(\mathrm{P}_{+j}-P_{i j}\right)\left(\frac{P_{i+}}{100-P_{j+}}\right), \forall \mathrm{i} \neq j \\
\mathrm{~L}_{\mathrm{ij}} & =\left(\mathrm{P}_{i+}-P_{i i}\right)\left(\frac{P_{+j}}{100-P_{+i}}\right), \forall \mathrm{i} \neq j
\end{aligned}
$$

\section{Driving forces of strong signal transitions}

In this study, binary logistic regression model was used to identify and quantify the interaction between the location of dominant signals (dependent variables) and explanatory parameters (independent variables) from 1986 to 2019 as indicated in Table 6. After communicating with stakeholders, spatial determinants such as topographic, hydrology, forest edge, accessibility, and demographic were identified. The slope, aspects, and drainages were generated from ASTER DEM $(30 \mathrm{~m} \times 30 \mathrm{~m})$. Drainage networks were derived from DEM with help of SWAT model in ArcGIS platform. The north-facing slope (cos aspect) and east-facing slope (sine aspect) were also generated from aspect to identify the location of systematic transitions. Commonly used human foot paths/trails in the park were digitized from IKONOS image. Proximate to river, road/trail networks and forest edge were calculated and reclassified. Similarly, transitions from woody vegetation to open-overgrazed land and from grassland to open-overgrazed land were identified as dependent variables over the past three decades (1986-2019). Hence, sampling observations of non-dominant and dominant transitions were assigned to 0 and 1 , respectively. The notation $\alpha$ is the intercept, and $\beta_{n}$ is the logit coefficient. The model assumes the dependent variables are the function of independent variables. Equation 9 which assumes the logit of probability is the logarithms of the odds. Linear logistic form which appeared as $p$ is the probability and corresponding of odds would be $p /(1-\mathrm{p})$. The explanatory variables in this study were expressed following the probability in Eq. 10. Equation 11 which formalizes the explanatory variables was standardized to zero mean $(\ddot{\mathrm{x}})$ and unit standard deviation $(\sigma \mathrm{x})$ to evaluate the relative importance of the independent variables in quantifying dominant signal transitions.

$$
\begin{aligned}
& \operatorname{Logit}(p)=\log \left(\frac{p}{100-P_{+i}}\right) \alpha+\beta_{1} X_{1}+\beta_{2} X_{2} \ldots \\
& +\beta_{n} X_{n} \\
& P=\frac{\exp \left(\alpha+\beta_{1} X_{1}+\beta_{2} X_{2} \ldots+\beta_{n} X_{n}\right)}{1+\exp \left(\alpha+\beta_{1} X_{1}+\beta_{2} X_{2} \ldots+\beta_{n} X_{n}\right)} \\
& X^{\prime} \mathrm{i}=\frac{X_{1-} \mathrm{X}^{\prime}}{\sigma \mathrm{X}}
\end{aligned}
$$

\section{Result}

\section{Accuracy assessment}

The classified maps of the study area 1986, 2005, and 2019 and the associated error matrix are presented in Fig. 2 and Table 2, respectively. Table 2 presents the error matrix value of $95.42 \%$ overall accuracy and associated Kappa coefficient (Khat) value of 94\% for 2019. Moreover, overall accuracies of $88.75 \%$ and $90.4 \%$ and associated Khat values of $87 \%$ and $94 \%$ were obtained for the reference years of classified maps of 2005 and 2019, respectively. Landis and Koch (1977) and Congalton and Green (2009) suggested that the Kappa statistics of a value greater than $80 \%$ indicated a strong agreement while a value ranging between $60 \%$ and $80 \%$ represents 


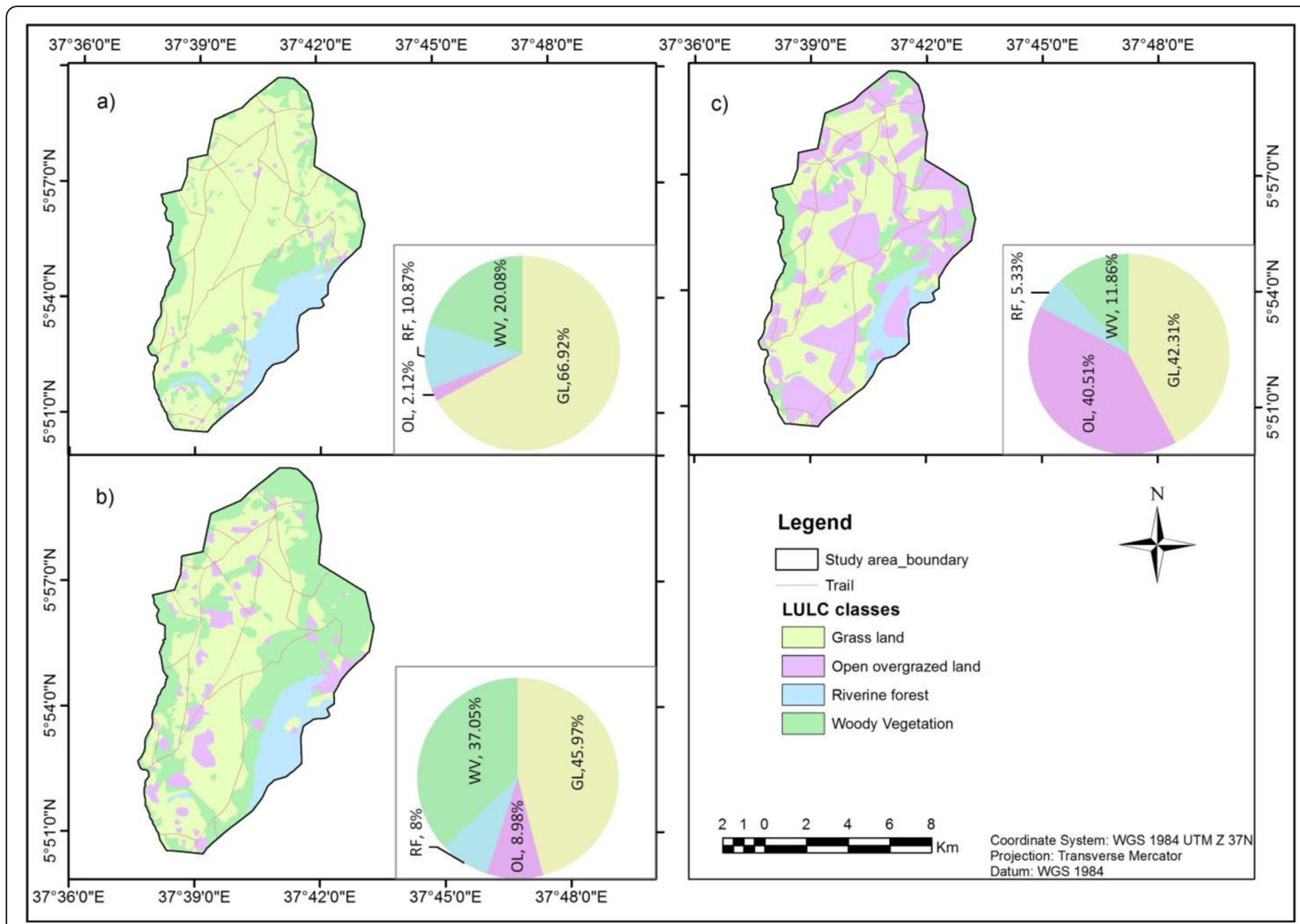

Fig. 2 Land use/land cover map of the main grassland plain of NSNP in 1986 (a), 2005 (b), and 2019 (c)

substantial agreement between the reference data and classified maps. Accordingly, in this study the error matrix report for all study periods presents the classified maps that met the accuracy requirements for change detection analysis (Anderson et al. 1976).

\section{Spatial extent and trends of land cover transitions}

Figure $2 \mathrm{a}-\mathrm{c}$ presents the LULC maps of the study area for the years 1986, 2005, and 2019. As indicated in
Table 3 in the period of 1986 and 2005 grasslands and woody vegetation were dominant classes roughly covering over $88 \%$ and $84 \%$ of the landscape, respectively, while in 2019 woody vegetation had lost its second position to open-overgrazed land (40.51\%). In 1986 grassland had covered more than two third of the landscape while woody vegetation and riverine forest covered $20.08 \%$ and $10.87 \%$ of the landscape, respectively (Fig. 2a, Table 3). Similarly, grassland and woody vegetation were

Table 2 Error matrix for the 2019 classified map

\begin{tabular}{|c|c|c|c|c|c|c|c|}
\hline & & \multicolumn{4}{|c|}{ Reference data 2019} & \multirow[b]{2}{*}{ Row total } & \multirow[b]{2}{*}{ UA (\%) } \\
\hline & & $\mathrm{GL}$ & $\mathrm{OL}$ & RF & WV & & \\
\hline \multirow[t]{7}{*}{ Classified data } & $\mathrm{GL}$ & 60 & 2 & 0 & 0 & 62 & 96.77 \\
\hline & $\mathrm{OL}$ & 3 & 57 & 1 & 0 & 61 & 93.44 \\
\hline & RF & 1 & 0 & 54 & 2 & 57 & 94.74 \\
\hline & WV & 0 & 0 & 2 & 58 & 60 & 96.67 \\
\hline & Column total & 64 & 59 & 57 & 60 & 240 & \\
\hline & PA (\%) & 93.75 & 96.61 & 94.74 & 96.67 & & \\
\hline & & & & & $K=0$. & $5.42 \%$ & \\
\hline
\end{tabular}


Table 3 Land use/land cover transition flow matrices for each span period (percentage)

\begin{tabular}{|c|c|c|c|c|c|c|c|c|c|c|c|c|}
\hline & $\mathrm{GL}$ & $\mathrm{OL}$ & $\mathrm{RF}$ & WV & $P_{\mathrm{i}+}$ & Loss & $C_{j}$ & $S_{j}$ & $D_{j}$ & $I_{\mathrm{p}}$ & $g_{p}$ & 9 \\
\hline \multicolumn{13}{|c|}{ 1986/2005 } \\
\hline GL & 40.30 & 5.99 & 0.16 & 20.48 & 66.92 & 26.62 & 32.30 & 11.35 & 20.95 & 0.66 & 0.14 & 0.21 \\
\hline $\mathrm{OL}$ & 0.49 & 0.97 & 0.01 & 0.66 & 2.12 & 1.16 & 9.17 & 2.31 & 6.85 & 1.19 & 8.27 & 6.93 \\
\hline RF & 0.80 & 0.69 & 7.75 & 1.64 & 10.87 & 3.12 & 3.37 & 0.50 & 2.87 & 0.40 & 0.03 & 0.08 \\
\hline WV & 4.39 & 1.34 & 0.08 & 14.28 & 20.08 & 5.80 & 28.58 & 11.61 & 16.97 & 0.41 & 1.60 & 3.92 \\
\hline$P_{+\mathrm{j}}$ & 45.97 & 8.98 & 8.00 & 37.05 & 100.00 & 36.71 & 36.71 & 12.89 & 23.8 .2 & & & \\
\hline Gain & 5.67 & 8.01 & 0.25 & 22.77 & 36.71 & & & & & & & \\
\hline \multicolumn{13}{|c|}{ 2005/2019 } \\
\hline GL & 26.65 & 18.35 & 0.00 & 0.97 & 45.97 & 19.32 & 34.98 & 31.31 & 3.67 & 0.73 & 0.59 & 0.81 \\
\hline $\mathrm{OL}$ & 3.08 & 5.67 & 0.01 & 0.22 & 8.98 & 3.31 & 38.15 & 6.62 & 31.54 & 0.58 & 6.15 & 10.53 \\
\hline RF & 0.34 & 1.92 & 5.25 & 0.49 & 8.00 & 2.75 & 2.83 & 0.16 & 2.67 & 0.52 & 0.02 & 0.03 \\
\hline WV & 12.23 & 14.57 & 0.07 & 10.18 & 37.05 & 26.86 & 28.53 & 3.34 & 25.19 & 2.64 & 0.16 & 0.06 \\
\hline$P_{+\mathrm{j}}$ & 42.30 & 40.51 & 5.33 & 11.86 & 100.00 & 52.25 & 52.50 & 20.96 & 31.54 & & & \\
\hline Gain & 15.65 & 34.85 & 0.08 & 1.67 & 52.25 & & & & & & & \\
\hline \multicolumn{13}{|c|}{$1986 / 2019$} \\
\hline GL & 34.71 & 28.26 & 0.11 & 3.85 & 66.92 & 32.21 & 39.81 & 15.18 & 24.62 & 0.93 & 0.22 & 0.24 \\
\hline $\mathrm{OL}$ & 0.72 & 1.22 & 0.01 & 0.18 & 2.12 & 0.91 & 40.20 & 1.81 & 38.39 & 0.75 & 32.28 & 43.32 \\
\hline RF & 1.90 & 2.99 & 5.23 & 0.76 & 10.87 & 5.65 & 5.75 & 0.21 & 5.54 & 1.08 & 0.02 & 0.02 \\
\hline WV & 4.98 & 8.05 & 0.00 & 7.06 & 20.08 & 13.02 & 17.81 & 9.58 & 8.23 & 1.84 & 0.68 & 0.37 \\
\hline$P_{+j}$ & 42.30 & 40.51 & 5.33 & 11.86 & 100.00 & 51.79 & 51.79 & 13.40 & 38.96 & & & \\
\hline Gain & 7.59 & 39.30 & 0.10 & 4.80 & 51.79 & & & & & & & \\
\hline
\end{tabular}

Note: the diagonal elements in italic represent the persistent (unchanged) LULC classes. $P_{\mathrm{i}+}=$ total in time $1, P_{+\mathrm{j}}=$ total in time $2, C_{\mathrm{j}}=$ total change, $S_{\mathrm{j}}=$ the amount of swap, $D_{\mathrm{j}}=$ the absolute value of net change, $I_{\mathrm{p}}=$ loss-to-persistence ratio, $g_{\mathrm{p}}=$ gain-to-persistence ratio, and $g_{\mathrm{l}}=$ gross gain-to-loss ratio

again the dominant land classes covered $45.97 \%$ and $37.05 \%$, respectively; however, to the opposite directions in 2005 (Fig. 2b). In 2019, grassland sustained its first position as a dominant class with a $42.3 \%$ of the landscape but decreased parallel with riverine forest throughout the study period. In the same year, open-overgrazed land took the second position with a $40.51 \%$ from woody vegetation which covered only $11.86 \%$ (Fig. 2c).

The trends of grassland, woody vegetation, and riverine forest decreased throughout the study periods, but the rate at which decreased were different. Although woody vegetation showed a drastic decline throughout the study periods following encroached dominant shrubs/bushes and invasive weed species it exhibited some expansion in the mid of 2000s. In contrast, open-overgrazed land had increased to the opposite directions of grassland, woody vegetation, and riverine forest for the period between 1986 and 2019.

\section{Gross gains, gross losses, persistence, net change, and swap change}

Table 3 presents transitions of LULC from one class to other classes including gains, losses, persistence, swaps, net changes, gain/loss to persistence ratios, and gain to loss ratios for each span period: 1986-2005, 2005-2019, and 1986-2019. Grassland, woody vegetation, and openovergrazed land were the three land cover classes dominated the gaining or losing even persisting landscapes over the past three decades (1986-2019). In terms of gains/losses, grassland, woody vegetation, and riverine forest experienced more loss, whereas open-overgrazed land experienced more gain from these classes. Losses in woody vegetation (13.02\%) and riverine forest (5.65\%) are more likely due to logging for fire wood and charcoal production and construction materials. Similarly, loss in grassland is most likely due to sowing and carrying grass for fodder, roof, and constructions and surge of mass livestock of the herdsman in the area. These substantial changes in land cover transitions which vary in each span period are presented separately below.

\section{6-2005}

During this period, a total gain of $36.71 \%$ has been recorded of which $22.77 \%$ was recorded by woody vegetation (Table 3). In terms of loss, grassland had lost $20.48 \%$ and $5.99 \%$ landscape to woody vegetation and open-overgrazed area, respectively, indicating encroachment and invasive weed species. Although about $40.30 \%$ and $14.28 \%$ of grassland and woody vegetation of the 
landscape remained persisted, both experienced high tendency quantitative net change but to opposite direction with a value of $-20.95 \%$ (about $65 \%$ of total change for its whole area) and $+16.97 \%$ (about $59 \%$ of total change for its whole area), respectively. In the same period, all land categories except for riverine forest experienced both swap and net changes. The change attributed to pixel transition location (swap) was highest for woody vegetation and grassland with a value of $11.61 \%$ ( $41 \%$ of total change for its whole area) and $11.35 \%$ (35\% of total change for its whole area), respectively. This indicates woodland captured $\sim 20 \%$ of grassland category, and at the same time, it had lost $\sim 4 \%$ to the same category than other classes. In terms of gain-to-persistence ratio $\left(g_{p}\right)$, loss-to-persistence ratio $\left(l_{p}\right)$, and gain-to-loss ratio were higher for open-overgrazed area, signifying that this category experienced simultaneously more gain and loss than to persist, while it showed more gain than loss to other category. Similarly, grassland attributed to strong loss than to persist and gain, but relatively to persist than to gain. By contrast, woody vegetation experienced more gain than persistence and resisted to loss.

\section{5-2019}

In contrast to the former period, this period was characterized by a reverse of the category. In this period, all land class category except open-overgrazed area had declined (Table 3). The highest losses and gains were recorded $(52.50 \%)$ than other periods did. The total loss of woody vegetation showed $26.86 \%$ of which $14.57 \%$ and $12.23 \%$ of the category had lost to open-overgrazed land and grassland, respectively, suggesting that woodland deforestation that have taken place in the park created chance for regeneration of grass (12.23\%). All land use/ land cover categories except riverine forest experienced swap and net change. The attributed change to landscape location change (swap) was higher for grassland (about $89 \%$ of its total area), but the net change was higher for open-overgrazed land $(+31.54 \%$, i.e., $83 \%$ of its total area), suggesting the grassland ecosystem faced huge degradation spatially eastern, northern, central, and south-central part of the park. In terms of loss-topersistence ratio (lp), woody vegetation experienced higher lost than to persist (2.64\%), followed by grassland $(0.73 \%)$, whereas high gain-to-persistence ratio observed in open-overgrazed area (6.15\%), suggesting massive destruction of woodland due to increasing the domestic energy such as charcoal for sale and use and construction of new houses and fences. Moreover, all crucial land classes except open- overgrazed land had lost than gaining, suggesting no proper management of policy seen after withdrawal of the African park foundation from management.

\section{6-2019}

Over the past three decades (1986-2019), all land categories except open-overgrazed land drastically declined (Table 3). About $51.79 \%$ of the total lost was recorded of which $28.26 \%$ of grassland, $8.05 \%$ of woody vegetation, and $2.99 \%$ of riverine forest had lost to open-overgrazed land, suggesting increasing the demand of fodder for livestock, illegal, and official resettlement of pastoralists and agro-pastoralists, fragmentation of land to implement farm along the dispersal areas, accessibility of water resources, and dark woodland within the park, frequent drought, and conflict. The change attributed to location (swap) was higher for grassland with a $15.18 \%$ (38\% of its total area) and woody vegetation with a $9.58 \%$ (54\% of its total area). The attribute to loss-topersistence ratio $\left(l_{p}\right)$ for all categories with the exception of open-overgrazed land showed nearly one and above while the gain-to-persistence ratio $\left(g_{p}\right)$ for all categories except open-overgrazed land were zero. It indicated that woody vegetation, riverine forest, and grassland had tended to lose more than to persist, whereas openovergrazed land persisted more than losing, but it tended to gain more than to persist. Except this category, the result for gross-to-loss ratio $\left(g_{1}\right)$ for grassland, riverine forest, and woody vegetation were zero, suggesting these categories were more losers than receivers.

\section{Detection of random and systematic transitions}

Table 4 and Fig. 3 show the observed and expected gains and losses for each land cover class under random process of gain and loss, and coupled with their difference between observed and expected gains and losses. The results indicated that random and systematic land cover transitions observed in each study period: 1986, 2005, and 2019 in the main grassland plain of NSNP. The expected values of the gain in land cover transition at a given persistence under a random process of change are presented in off-diagonal elements. In LULC transitions under random process gains, the value of large positive value obtained from the difference between observed and expected gains indicates systematic gains. Accordingly, open-overgrazed land systematically gained $(\sim 1.4 \%)$ from grassland. However, grassland systematically gained $(\sim 0.4 \%)$ from woody vegetation. Hence, the transition of $28.26 \%$ of landscape from grassland to openovergrazed land was due to a systematic process of change. In contrast, large negative values such as open-overgrazed land and grassland from riverine forest, woody vegetation from grassland, and riverine forest from woody vegetation all indicated systematically avoided gaining.

The difference between the observed values and expected losses under a random process of loss was higher for grassland and woody vegetation to open-overgrazed land by $5.64 \%$ and $1.35 \%$, respectively, suggesting 
Table 4 Percent of land cover transitions in terms of gains $\left(G_{\mathrm{ij}}\right)$ and losses $\left(L_{\mathrm{ij}}\right)$ during $1986-2019$

\begin{tabular}{|c|c|c|c|c|c|c|c|}
\hline $1986 / 2019$ & Variables & $\mathrm{GL}$ & $\mathrm{OL}$ & $\mathrm{RF}$ & WV & $\mathrm{P}_{\mathrm{i}+}$ & Loss \\
\hline \multirow[t]{4}{*}{$\mathrm{GL}$} & $G_{i j}$ & 34.71 & 26.87 & 0.08 & 4.01 & 65.67 & 30.96 \\
\hline & $L_{i j}$ & 34.71 & 22.62 & 2.98 & 6.62 & 66.92 & 32.21 \\
\hline & $\mathrm{D} G_{i j}$ & 0.00 & 1.39 & 0.03 & -0.16 & 1.25 & 1.25 \\
\hline & $\mathrm{D} L_{i j}$ & 0.00 & 5.64 & -2.87 & -2.77 & 0.00 & 0.00 \\
\hline \multirow[t]{4}{*}{$\mathrm{OL}$} & $G_{i j}$ & 0.49 & 1.22 & 0.00 & 0.13 & 1.83 & 0.62 \\
\hline & $L_{i j}$ & 0.65 & 1.22 & 0.08 & 0.18 & 2.12 & 0.91 \\
\hline & $\mathrm{D} G_{i j}$ & 0.23 & 0.00 & 0.01 & 0.05 & 0.29 & 0.29 \\
\hline & $\mathrm{D} L_{i j}$ & 0.07 & 0.00 & -0.07 & 0.00 & 0.00 & 0.00 \\
\hline \multirow[t]{4}{*}{$\mathrm{RF}$} & $G_{i j}$ & 2.50 & 4.36 & 5.23 & 0.65 & 12.74 & 7.51 \\
\hline & $L_{i j}$ & 2.52 & 2.42 & 5.23 & 0.71 & 10.87 & 5.65 \\
\hline & $\mathrm{D} G_{i j}$ & -0.60 & -1.38 & 0.00 & 0.11 & -1.87 & -1.87 \\
\hline & $\mathrm{D} L_{i j}$ & -0.63 & 0.57 & 0.00 & 0.06 & 0.00 & 0.00 \\
\hline \multirow[t]{4}{*}{ WV } & $\overline{G_{i j}}$ & 4.61 & 8.06 & 0.02 & 7.06 & 19.75 & 12.69 \\
\hline & $L_{i j}$ & 6.25 & 5.98 & 0.79 & 7.06 & 20.08 & 13.02 \\
\hline & $\mathrm{D} G_{i j}$ & 0.37 & -0.01 & -0.02 & 0.00 & 0.33 & 0.33 \\
\hline & $\mathrm{D} L_{i j}$ & 0.80 & 1.35 & 0.00 & 1.00 & 1.00 & 1.00 \\
\hline \multirow[t]{4}{*}{$P_{+j}$} & $G_{i j}$ & 42.30 & 40.51 & 5.33 & 11.86 & 100.00 & 51.79 \\
\hline & $L_{i j}$ & 44.13 & 32.24 & 9.07 & 14.57 & 100.00 & 51.79 \\
\hline & $\mathrm{D} G_{i j}$ & 0.00 & 0.00 & 0.00 & 0.00 & 0.00 & 0.00 \\
\hline & $\mathrm{D} L_{i j}$ & -1.82 & 8.28 & -3.74 & -2.71 & 0.00 & 0.00 \\
\hline \multirow[t]{4}{*}{ Gain } & $G_{i j}$ & 7.59 & 39.30 & 0.10 & 4.80 & 51.79 & \\
\hline & $L_{i j}$ & 9.42 & 31.02 & 3.84 & 7.51 & 51.79 & \\
\hline & $\mathrm{D} G_{i j}$ & 0.00 & 0.00 & 0.00 & 0.00 & 0.00 & \\
\hline & $\mathrm{D} L_{i j}$ & -1.82 & 8.28 & -3.74 & -2.72 & 0.00 & \\
\hline
\end{tabular}

Note: $G_{i j}=$ expected gain under random process of gains, $L_{i j}=$ expected loss under random process of losses, DG $G_{i j}=$ the difference between the observed and the expected value under random process of gain, $\mathrm{DL}_{\mathrm{ij}}=$ the difference between the observed and the expected under random process of loss. The most systematic transitions are highlighted

grassland systematically losing to open-overgrazed land; yet, open-overgrazed land slightly avoided systematically gaining from woody vegetation $(-0.01 \%)$. Thus, no absolute systematic transition was observed in the woody vegetation to open-overgrazed land though systematically losing to open-overgrazed land. In the same process, woody vegetation and open-overgrazed areas were systematically losing to grassland $(\sim 1 \%)$ and $(0.07 \%)$, respectively. At the same time, grassland systematically gaining from the woody vegetation $(\sim 0.4 \%)$ and from open-overgrazed land $(0.23 \%)$ while slightly avoided gaining from woody vegetation $(-0.01 \%)$. Despite poor regeneration of grass on the open-overgrazed land and deforested area, the carrying capacity for the landscape of grassland would result in overgrazing and would decline in livestock population due to shortage of pasture (Teferi et al. 2013).
Therefore, the conversion from woody vegetation to grassland $(\sim 5 \%)$, from grassland to open-overgrazed land $(28.26 \%)$, the conversion of open-overgrazed land to grassland $(0.72 \%)$, and from riverine forest to woody vegetation $(0.76 \%)$ were observed to be the fully systematic transitions while conversion from woody vegetation to open-overgrazed land $(8.05 \%)$ is partly systematic transition, and the rest experienced random transitions during 1986-2019 in the main grassland plain of NSNP.

\section{Determinants of the locations of the most systematic transitions}

Based on their degree of the high tendency of systematic transitions, the conversion from woody vegetation to grassland and from grassland to open-overgrazed land was selected among other fully systematic transitions observed between 1986 and 2019 (Table 4, Figs. 4 and 5). 


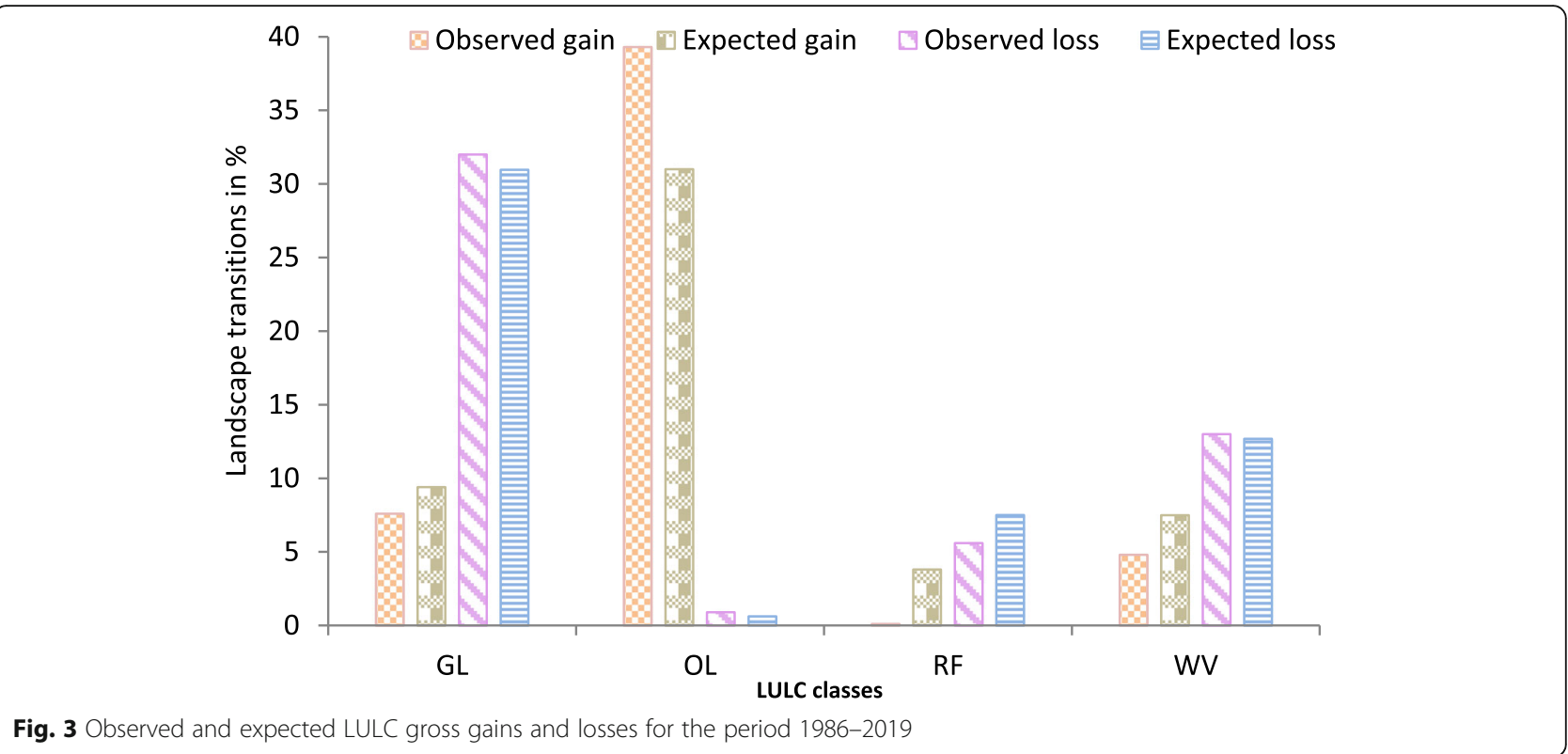

Fig. 3 Observed and expected LULC gross gains and losses for the period 1986-2019

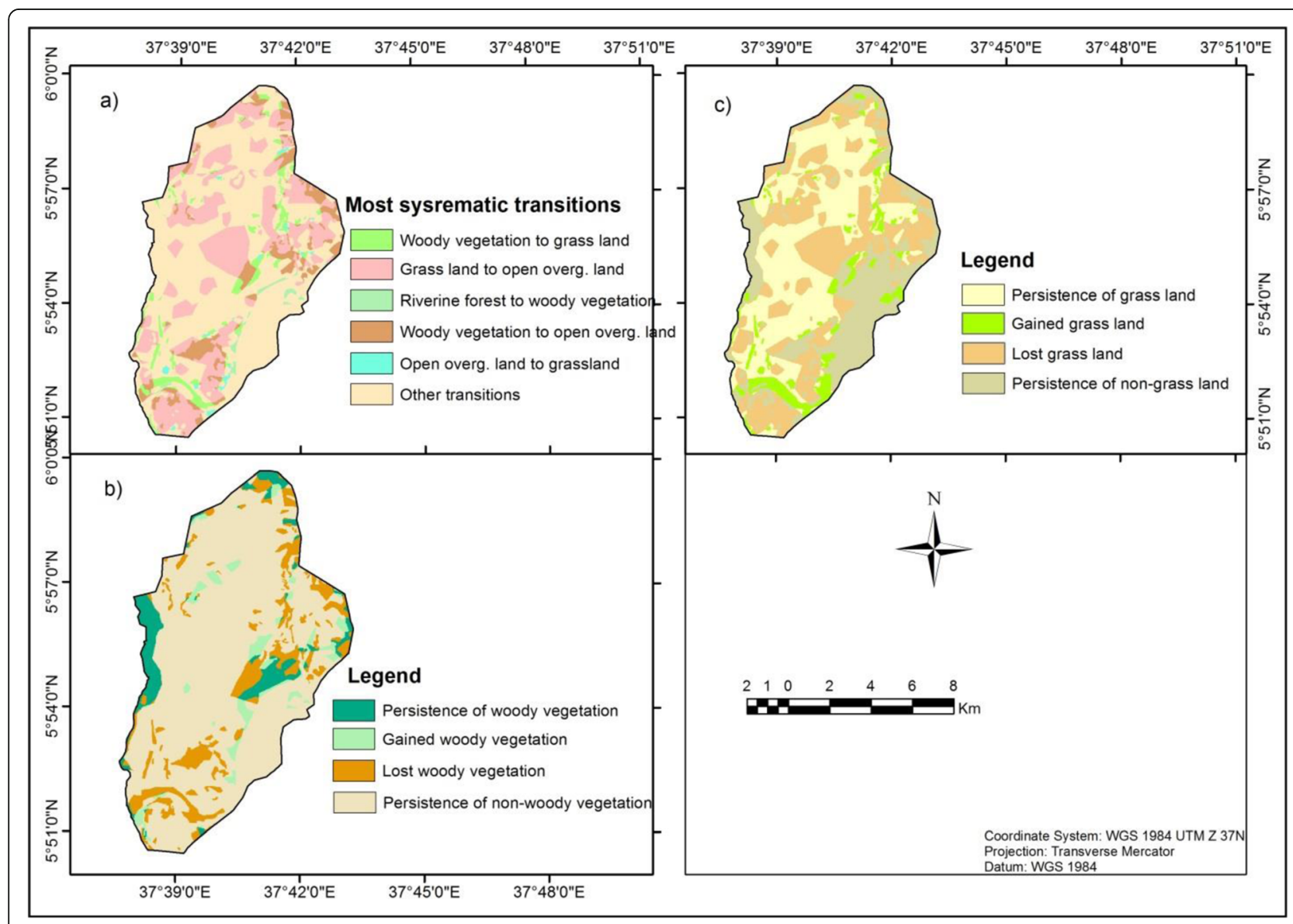

Fig. 4 Map of the systematic land cover transitions between 1986 and 2019 (a), and spatial representation of the gains, losses, and persistence experienced in woody vegetation (b) and grassland (c) 


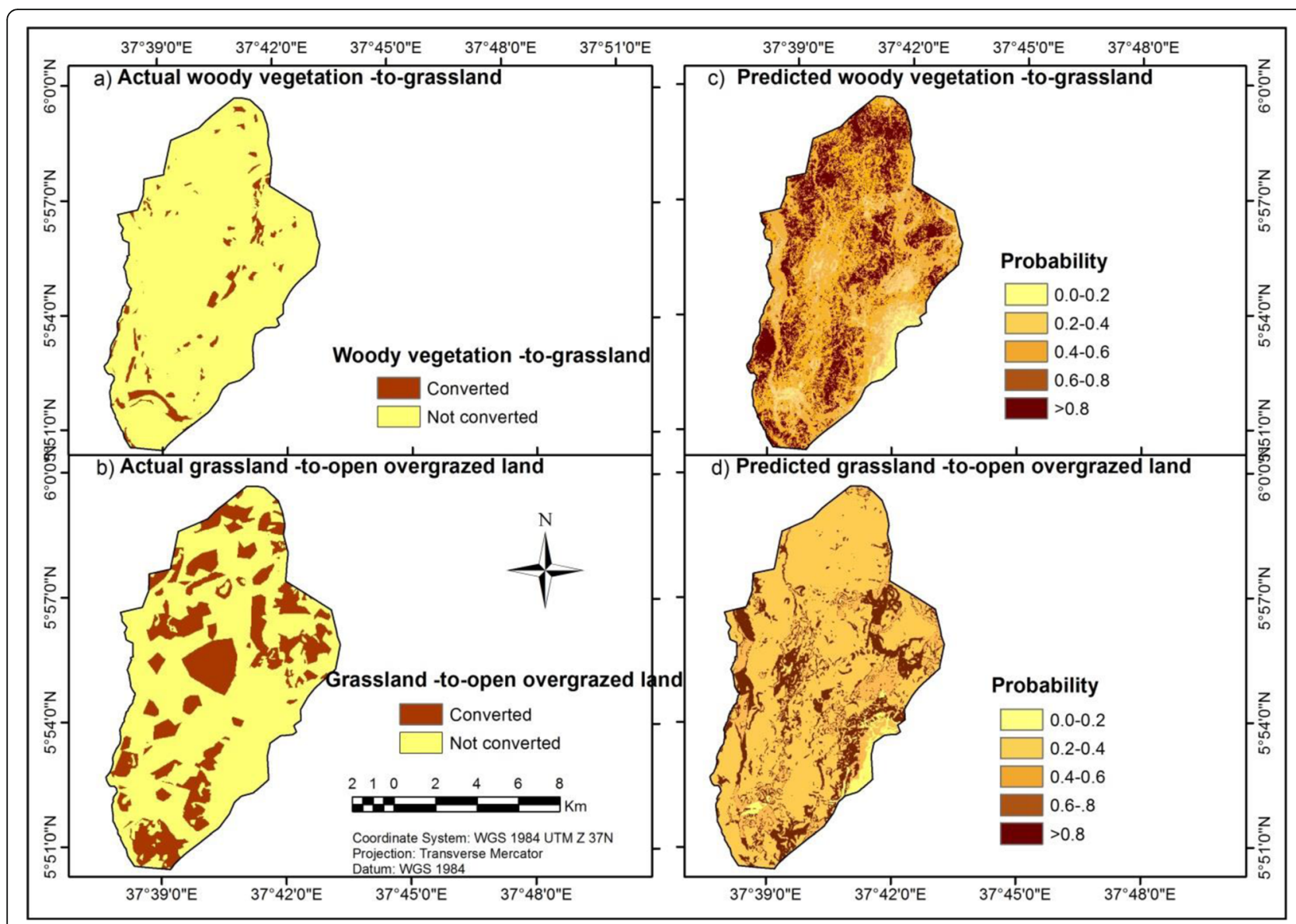

Fig. 5 Actual conversion for the period 1986-2019 (a and b) and predicted conversion based on the logistic regression model (c and d)

To identify and analyze the parameters that determine the patterns, a prediction model of binary logistic regression analysis was conducted. In this regard, seven major determinants were identified and analyzed (Table 6). In addition to these determinants, five other determinants were identified after ground survey and interview techniques conducted (Table 5). Relative operating characteristic (ROC) was constructed to discriminate between classes and to test the errors incurred in the predicted model for better decision rule (Fig. 5 and Table 6).

\section{Woody vegetation to grassland land conversions}

The binary logistic regression model for woody vegetation to grassland transition was selected $\left(X^{2}=50,739.9\right.$, $d f=1, p<0.000, N=116,492$, Nagelkerke pseudo variance or $R^{2}=0.59$ ) for detecting the triggers inducing this change (Table 6). The ROC for Fig. 5a, c shows an accuracy of 0.80 (80\%) in Fig. 6a, c, indicating the goodness of fit of the model is excellent to the rating explained by (Hosemer and Lemeshow 2000). The model also showed the overall percentage corrected classification of a value $92.4 \%$. The determinants of changes indicated in Table 6 explained topographic variables (elevation) which positively associated with transition from woody vegetation to grassland whereas inversely proportion with distance variables. In line with this, the east-facing slope (sine of aspect) did not have any statistically significant contribution to woody vegetation-tograssland conversion in the main grassland plain of the NSNP.

Topography-related variables The positivity of the topographic variable indicates the likelihood of forest-tograssland conversion increases with increasing elevation (Table 6). The entirety of the study area lies within elevation ranging from $960-1469 \mathrm{~m}$ experienced tropical climate. Hence, massive woodland destructions observe relatively in higher altitude areas $(1050-1250 \mathrm{~m})$ is related with standard deviation of 0.827 , suggesting densely populated of pastoralists and agro-pastoralists are settled close and in the park. However, woody vegetation-to-grassland conversion decreases with increasing steepness of a location, suggesting more than half of the woody vegetation confined along the gentleto-moderately steep slope and only small portion of woodland are found in the inaccessible areas. This is due 
Table 5 List of driving forces for systematic land cover transitions in the NSNP

\begin{tabular}{|c|c|c|c|}
\hline Variables & Abbreviations & Units & Proxy for \\
\hline \multicolumn{4}{|l|}{ Topography variables } \\
\hline Elevation & ELEV & $\mathrm{m}$ & Mean annual temperature $\left({ }^{\circ} \mathrm{C}\right)$ \\
\hline Slope & SLP & Degrees & Diffuse solar radiation \\
\hline Sine of aspect & SIN_ASP & -1 to 1 & Eastness \\
\hline Cosine of aspect & COS_ASP & -1 to 1 & Northness \\
\hline \multicolumn{4}{|l|}{ Distance variables } \\
\hline Proximity to forest edge & DIS_WREDG86 & m & Likelihood for forest loss \\
\hline Proximity to roads/trails & DIS_RTRA & $\mathrm{m}$ & $\begin{array}{l}\text { Likelihood for forage use } \\
\text { and constructions }\end{array}$ \\
\hline Proximity to drainage networks & DIS_DRA & m & Accessibility \\
\hline Other driving forces & & & Causes \\
\hline Successive government policies & & & $\begin{array}{l}\text { Population pressure due to } \\
\text { population growth, villagization } \\
\text { programs, resettlements (formal/informal). }\end{array}$ \\
\hline Local climate incidence (drought) & & & Erratic rainfall (November-June) \\
\hline Education & & & $\begin{array}{l}\text { Lack of awareness on environmental } \\
\text { management and related issues. }\end{array}$ \\
\hline Political unrest & & & $\begin{array}{l}\text { Landholding crisis (e.g., Gedeo, Segen, } \\
\text { Borena, Guji I and II). }\end{array}$ \\
\hline Livelihood of the population & & & Movable pastoralism and agro-pastoralism. \\
\hline Geo-politics & & & $\begin{array}{l}\text { Frequent clan conflicts on park } \\
\text { border demarcation. }\end{array}$ \\
\hline
\end{tabular}

Table 6 Binary logistic regression results for the transitions from woody vegetation-to-grassland and grassland-to-open-overgrazed land

\begin{tabular}{|c|c|c|c|c|c|}
\hline Dependent variable & Model evaluation & Independent variables & ULC ( $\beta)$ & $\mathrm{SE}(\beta)$ & $\operatorname{SLC}\left(\beta^{*}\right)$ \\
\hline \multirow[t]{8}{*}{ WV-GL conversion (1986/2019) } & $\operatorname{LR} X^{2}=50,739.906$ & COS_ASP & 0.152 & 0.016 & 0.949 \\
\hline & $(\rho=0.000)$ & SIN_ASP & * & * & * \\
\hline & Nagelkerke $R^{2}=0.585$ & DIS_RTRA & -0.001 & 0.001 & -0.819 \\
\hline & $\mathrm{ROC}=0.80$ & DIS_DRA & -0.004 & 0.001 & -5.821 \\
\hline & & DIS_WREDG86 & -0.005 & 0.001 & -6.033 \\
\hline & & ELEV & 0.218 & 0.001 & 0.827 \\
\hline & & SLP & -0.005 & 0.001 & -0.415 \\
\hline & & Intercept & -0.386 & 0.003 & -0.08 \\
\hline \multirow[t]{7}{*}{ GL-OL conversion (1986/2019) } & $\operatorname{LR} X^{2}=3938.224$ & COS_ASP & 0.028 & 0.001 & 0.559 \\
\hline & $(\rho=0.000)$ & SIN_ASP & 0.001 & 0.002 & 0.124 \\
\hline & Nagelkerke $R^{2}=0.475$ & DIS_RTRA & -0.005 & 0.001 & -5.701 \\
\hline & $\mathrm{ROC}=0.690$ & DIS_DRA & -0.048 & 0.000 & -7.969 \\
\hline & & ELEV & -0.003 & 0.003 & -0.134 \\
\hline & & SLP & -0.017 & 0.002 & -2.817 \\
\hline & & Intercept & -4.823 & 0.196 & -0.92 \\
\hline
\end{tabular}




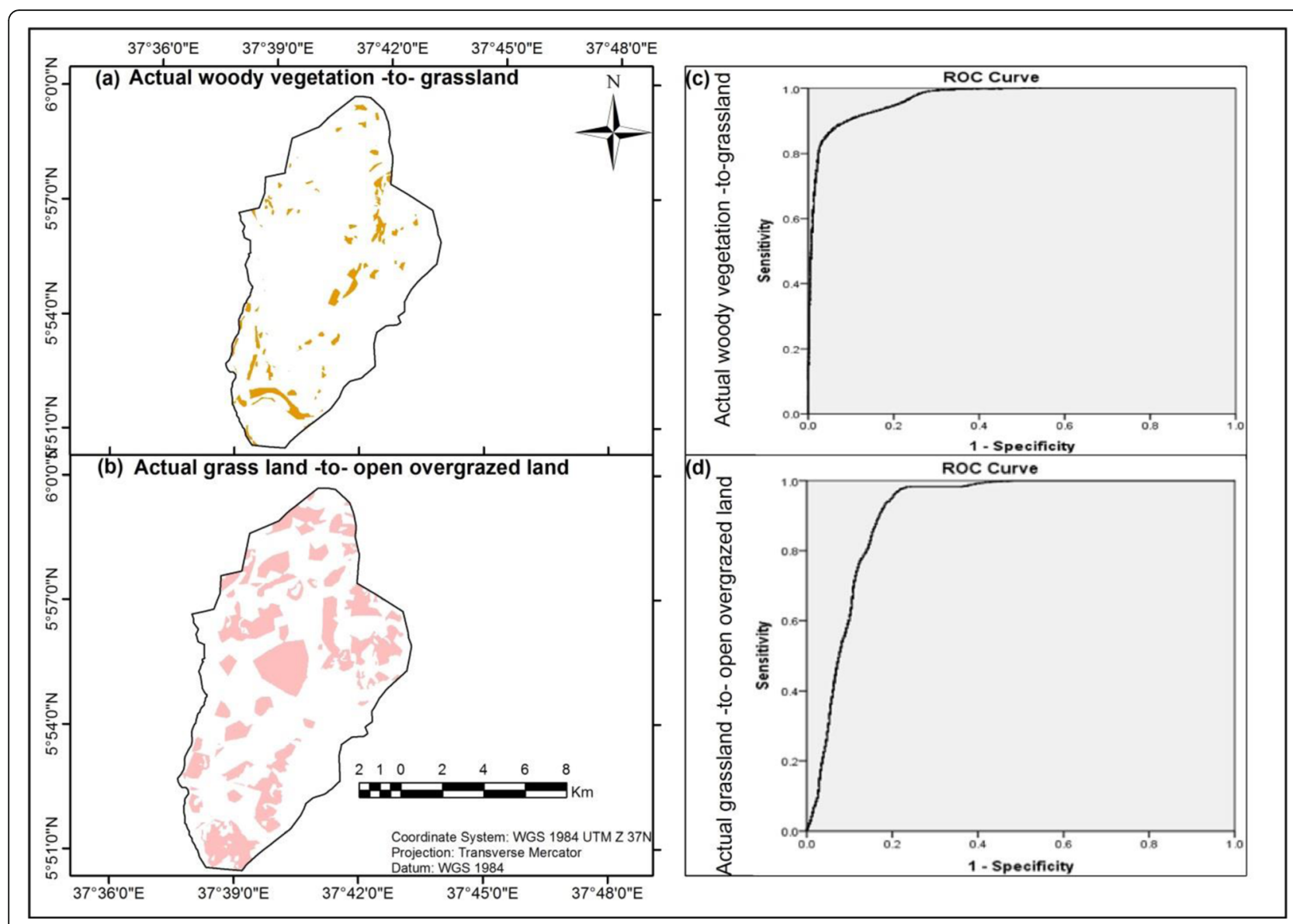

Fig. 6 Actual conversion between 1986 and 2019 ( $\mathbf{a}$ and b) and validation ROC curve for the model (c and d)

to the fact that the study area predominantly lies in the lowland area which comprises flat and gentle slope areas. Similarly, deforestation increases with approaching to the north-facing slope (cosine of aspect), suggesting the area surrounded by resettled communities (northern, northwestern) where avifaunas are common. Statistically, the conversion to grassland predicted probability was $0.6-0.85$ for this facing slope at $22.5-67.5$ and $335-375$.

Distance variables All statistically significant distance variables (forest edge, drainage, and trails) are negatively correlated with woody vegetation-to-grassland conversion (Table 6). It implies that deforestation increases with decreasing distance from drainage, forest edge, and trails. Variable distance from forest edge, drainage, and trails appear to have strong effect in woody vegetationto-grassland conversion. The spatial explicit model explains that the probability of deforestation increases from 0.35 to 0.73 as the distance from forest edge decreases from 0.3 to $0 \mathrm{~km}$, suggesting wood and shrubs are tough sources of energy and income, and construction materials. Moreover, land fragmentation due to resettlement and in searching of croplands could have a great impact on wood-shrub landscapes. However, the predicted probability of woodland conversion decreases to 0.014 as the distance from the forest edge particularly at $0.76 \mathrm{~km}$ increases, suggesting relatively better solution for conservation of woodland to grassland due to deforestation. On the other hand, the predicted probability of deforestation increases from 0.4 to 0.83 for a decrease in distance from 0.5 to 0 $\mathrm{km}$. Moreover, the spatial explicit model indicates woody vegetation located close to drainages seems to have higher likelihood of being converted to grassland. The other distance variable trail is also found to be a statistically significant predictor of location of woody vegetation-to-grassland conversion. The model also explains that the predicted probability of the likelihood of forest-to-grassland conversion increases from 0.4 to 0.8 for a decrease in trail distance from 0.5 to $0 \mathrm{~km}$ than at a distance of 0.25 . Therefore, a $0.75 \mathrm{~km}$ buffer of existing can protect and manage it from conversion to grassland (Fig. 7a).

\section{Grassland to open-overgrazed land conversions}

The logistic regression model as a whole explained $\left(X^{2}=3938.224, d f=1, p<0.000, N=5890\right.$, Nagelkerke pseudo variance or $\left.R^{2}=0.475\right)$ and correctly classified 


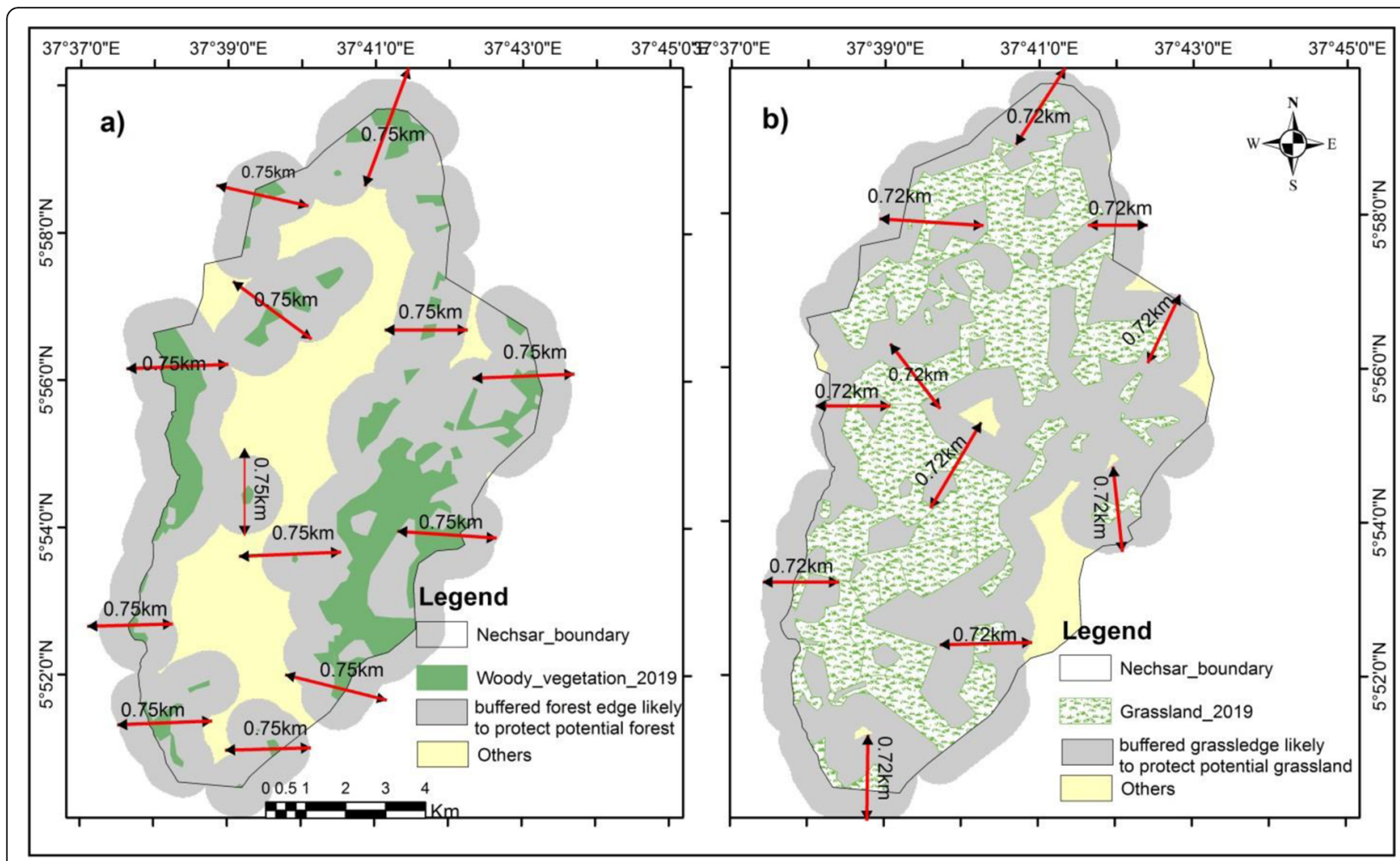

Fig. 7 Recommended buffers likely to protect the existing forests from further deforestation (a), and grassland from degradation (b) after predicted model simulated in Fig. 5 and effectively validated in Fig. 6

$85.3 \%$ of the cases (Table 6). A $69 \%$ of ROC value for Fig. $5 \mathrm{~b}, \mathrm{~d}$ of the spatial explicit model fit is generally good (Table 6 and Fig. 6b, d). The model shows that proximate to drainage and trial, elevation, and steepness of location negatively correlated to grassland-toopen-overgrazed land conversion. Yet, the east-facing (sine of aspect) and north-facing (cosine of aspect) slope positively engaged in grassland-to-open-overgrazed land conversion.

Topography-related variables The aspect variables have statistically significant positive relationship with grassland-to-open-overgrazed land conversion, indicates the likelihood of this conversion increases to north and east facing slope (Table 6). The predicted probability increases from 0.25 to 0.43 and from 0.2 to 0.35 to the north $(22.5,67.5$, and 335) and east (90) facing slopes. The location is also associated with availability ecosystem services. However, the likelihood conversion of grassland-to-open-overgrazed land relatively increases with decreasing of elevation. The spatially explicit model illustrated in Table 6 and Fig. 6b, d indicates that the predicated probability of grassland-to-open-overgrazed land $(0.5-0.7)$ is higher on former deforested areas and grazed areas (1200-970 m).
Distance variables All statistically significant proximate trails and drainage are negatively correlated with grasslandto-open-overgrazed conversion (Table 6). It implies that overgrazing increases with decreasing distance from drainage and trails. The model predicted a probability of conversion from grassland-to-open-overgrazed land increases from 0.35 to 0.55 for a decrease in trail distance from 0.5 to $0.2 \mathrm{~km}$. Similarly, the spatially explicit statistical model indicates that the likelihood of conversion from grassland-toopen-overgrazed land greatly increases with decreasing of a distance from the drainage. The predicted probability of open-overgrazing increases from 0.48 to 0.8 as the distance from drainage decreases from 0.5 to $0 \mathrm{~km}$ implies increasing the demand of water resources. Furthermore, the field observation and key informants' interview also confirmed that long-term drought, conflict, and the geo-politics (on park border) have been aggravated with the migration of local communities and their livestocks to the park for the safe (Table 5). This also put adverse pressure on avifauna over the past two decades in the study area.

\section{Discussion}

\section{Spatial extent and trends of land cover transitions}

The results indicated the main grassland plain of NSNP had experienced significant landscape transformation since the mid-1980s. Grassland, woody vegetation, and open- 
overgrazed land were the three land cover classes dominated the gaining or losing even persisting landscapes, suggesting these may have been driven by a combination of biophysical conditions, accessibility, and coupled with other human-induced and policy drivers over the past three decades (1986-2019). The highest loss of woody vegetation was observed during the second study period (26.86\%) as compared to the first period (only 5.8\%). This was relatively the opposite of grassland which experienced higher loss in the first period (26.62\%) than the second period (19.32\%). Grassland experienced a significant loss to woody vegetation and open-overgrazed land mainly in the first and second study periods, but it was found to be relatively the most persisted land cover class (34.71\%) during the period 1986-2019.

All the study span periods, 1986-2005, 2005-2019, and 1986-2019, had experienced clear land cover transformation indicating distinct changes in biophysical conditions, accessibility, lack of public awareness on environmental-related issues, population growth, policy, urban/market expansions, local climate incidence, and geo-political issues. The first period (1986-2005) was characterized by simultaneous expansion and destruction of woody vegetation. Woody vegetation recorded a total loss of $5.8 \%$, of which $\sim 4.4 \%$ had lost to grassland. The loss in woody vegetation was most likely due to increasing the demand of wood for fuel and charcoal production, whereas massive gain from grassland (20.48\%) was mainly due to encroachment. The dry savanna grassland has been encroached by woody/shrub species such as Dichrostachys cinerea, Acacia mellifera, A. nilotica, A.oerfota, A. seyal, Abutilon anglosomaliae, and A. bidentatum, only to mention a few (Sivalek 2008; Yusuf et al. 2011; Fetene et al. 2016) that have aggressively substituted the grassland. These were marked by massive condensed of forage, thereby led to grassland degradation mainly in the main grassland plain of NSNP. A similar finding has also been observed in Awash National Park, Ethiopia, where encroached vegetation had expanded through encroachment and occupied large territory of grassland (Belay et al. 2014). However, the shrub land expansion reported in Semien Mountain National Park was attributed to regrowth through strong management strategy against land fragmentation for agriculture and pasture in the area (Menale et al. 2011). The gain-to-loss ratio of $3.92 \%$ and $6.93 \%$ was highest for open-overgrazed area and woody vegetation, indicating that overgrazing and deforestation experienced four times and seven times more gains than loss as presented in Table 3. The replacement of grassland by woody species and invasive herbaceous plants was marked that this grassland ecosystem is the most threatened habitats. Similarly, the drastic decline of grassland was piloted animal herds to rely on small plot of land in turn led to overgrazing which may exposed to degradation (6\%). Grassland degradation accompanied by illegal hunting and firing resulted in rapid diminishments of wildlife. For instance, studies in this park indicated Swayne's hartebeest reported to have declined from 103 individuals in 1973 to 40 in 1992 (Bolton 1973; Duckworth et al. 1992).

Unlike the first study period, the second study period (2005-2019) was marked by a reverse in the land cover transitions. The period was particularly marked by habitat destruction due to massive forest destruction and followed by overgrazing. Loss in riverine forest $(2.75 \%)$ and woodland $(26.86 \%)$ is associated with forest abandonment outside of protected areas. During this period, woodland drastically decreased due to land abandonment through resettlement/villagization programs of mid-1980s where people from highly densely settled areas were relocated to sparsely populated lowlands (Rahmato 2009). This program which offers pastoralists and agro-pastoralists mainly from Guji I and II, Borena, Sile, Gedeo, Gamo, Segen, Amaro, and landless peoples from Arbaminch environs and private investors is taking place around and in the park. The lives of these settlers are entirely dependent on the natural resources of the park for their livelihoods and their capital assets (livestocks). Hence, the continual destruction of forest for logging for firewood and charcoal productions, constructing new houses and fences, and urban/market expansions put adverse pressure on the avifauna of the park. Similar studies have also been reported in the semi-arid region of Tsava-West National Park, Kenya, by Syombua (2013) that forest and woodland together decreased by more than 65\% between 1987 and 2011, and the triggered factors were human-induced and poor management policy along the park attributed to habitat degradation. Moreover, long-term drought due to erratic rainfall and long-term unsolved conflict between these pastoralists due to complex boundary demarcation forced them with their livestock to settle in the park. Similar findings have also been reported in Awash $\mathrm{Na}$ tional Park (Belay et al. 2014) and Yabelo wildlife reserve (Regassa and Yirga 2013) in Ethiopia. Both studies suggested that clan conflicts due to boundary demarcation resulted communities to surge into the protected areas illegally. This finally marked overgrazing which is the first sign of habitat degradation.

The gain-to-loss ratio of $10.53 \%$ was highest for openovergrazed area, indicated that open-overgrazed area experienced ten times more gain than loss mainly at the expense of grassland (18.35\%). It is vivid that the wildlife in the main grassland plain is enclosed from north by Abaya, south by Chamo lakes, eastern by Sermele river, and the part has villages and west is occupied by Arbaminch town. Thus, animal cannot migrate and easily fell 
prey to hunting and poaching by herdsman. The current statistics revealed that over 2000 zebras are left alone just because their flesh is not edible. By contrast, the Swayne's hartebeest whose species is endangered to be extinct declined from 35 individuals in 2008 to only 12 in 2010 and to four in 2014 (Mamo et al. 2012; Fetene et al. 2016). Similarly, Grant Gazelle, lesser and greater Kudus, bush and water-backs, and other mammals with no habitat are hunted down and pushed on the brink of extinction. Fetene et al. (2016) had also suggested that wide spread decline of vegetation and grassland particularly after 2007 mainly linked to poor management and conservation policy of Ethiopian wildlife conservation authority (EWCA) as compared to previous park management enforcement of NSNP under African parks foundation (private-public management). Since then, nothing has been done more than earning money from local and foreign tourists. The NSNP park particularly the main grassland plain which owes endemic and endangered animals is believed to be visited by more than 40, 000 visitors per annum. Although the study area has been served as the day to day activities of animal feeding, resting, team met opportunities, and reproduction, the habitat is rapidly devastated over the past three decades (1986-2019).

\section{Detection of the most systematic transitions}

The analysis of the result in Table 4 also identified systematic land cover transitions observed during the entire study period (1986-2019) by comparing the observed to the expected transitions arising from chance for any degree of unchanged landscape (Pontius 2004; Braimoh 2006; Alo and Pontius Jr 2008). As indicated in Table 4 and Fig. $4 \mathrm{a}-\mathrm{c}$, the simultaneous gains and losses of woody vegetation and grassland, grassland and openovergrazed land, and woody vegetation and riverine forest were recorded as the systematic land cover transitions. Accordingly, the gain in grassland from woody vegetation is clear systematic, suggesting when grassland gains, the new grass likely to gain systematically from deforested wood beneath. In other words, when wood loses, grass replaces it (Figs. $4 \mathrm{~b}$ and $5 \mathrm{a}, \mathrm{c}$ ). Similarly, woody vegetation is systematically losing to grassland, suggesting when woody vegetation was cut, the grass systematically occupied it. Therefore, massive deforestation in the park due to increased demand of wood for fuel and charcoal productions, constructions, and market expansions is further hailed to grass by systematically lose to grassland. Consequently, open-overgrazed land systematically gained from grassland, and grassland systematically gained from open-overgrazed land in Fig. 4a, c, indicating fully systematic exchange of landscape portion among the two land cover classes as a result of opposed interplay between the drivers of overgrazing against rehabilitation. This also implies that when openovergrazed land systematically gained from grassland, whereas by reverse it systematically loses to grassland (Table 4). Likewise, woody vegetation gained from riverine forest is relatively systematic, suggesting when woody vegetation gains, the new encroached and invasive wood species tends to gain systematically from riverine forest (Fig. 4a, b). However, all the rest gains/losses of land cover transitions in this study is either random and or partially systematic changes which may lead to systematic change due to biophysical, accessibility, demographic and successive government policy, and others (Pontius 2004; Braimoh, 2006; Alo and Pontius Jr 2008).

\section{Determinants of the locations of the most systematic transitions}

Drivers of changes in land cover in the main grassland plain of NSNP were identified (Table 5). Finally, the spatial determinants of the strong signal transitions were identified and quantified using the spatially explicit statistical model for the period 1986-2019 (Table 6). Because of changes in spatial determinants of land cover distributions, some land cover classes attempted to compute each other and one another more than other classes (Figs. 5 and 6a, b). Accordingly, the conversion of woody vegetation initially to grassland and subsequently grassland to open-overgrazed land were found to be the most systematic land cover transitions as compared to other classes (Fig. 5a). These classes experienced simultaneous gains and losses of land cover transitions, attributed to strong signal landscape changes (Pontius 2004; Braimoh 2006; Teferi et al. 2013). Forest edges, medium-to-high elevation, north-facing and moderately steep-to-gentle slopes, locations near trails and drainages, and population growth, accompanied by other determinants such as, successive policy, local climate incidence, and geopolitics increase the likelihood of woodland-to-grassland conversion (Figs. 5 and 6a, c). Therefore, based on these spatial determinants, the resettled peoples in and around the main grassland plain of the park whose livelihood entirely depends on rising animals and growing crops, hunting, fishery, and forestry could put adverse pressure on the remaining forests. It is certain that the park has shortage of infrastructures mainly road except the western edge, but the main grassland plain of the park consists of several trails which have been served human and livestock movements to the drainages (Chamo \& Abaya lakes, and Sermele river), wildlife, and fodder availability. Therefore, in terms of proximity, the forests (woody vegetation and riverine forest) located near to drainages and trails are likely to be grassland (Fig. 5a, c). However, the predicted probability at the distance of $0.75 \mathrm{~km}$ buffer of existing forests confined near to drainages, roads/ trails, and forest edges are generally close to 0.01 . This 
implies it is likely to protect forests located near drainages, roads, and forest edges from conversion to grassland as a result of increasing the demand of logging for firewood and charcoal productions, construction materials, market expansions, pasture, and cropland expansions. On the other hand, the lower elevation, easting and northing facing gentle slopes, locations near to drainages and trails, accompanied by frequent drought, and geo-politics on border demarcation heighten the likelihood of conversion grassland to open-overgrazed land. The spatial explicit statistical model showed that grasses located near to drainages, trails, and on the lower elevation, on the east, and north facing and gentle slopes are more likely to be open-overgrazed areas (Figs. 5 and $6 \mathrm{~b}, \mathrm{~d})$. The communities use these trails as alternative movements to sow grasses for the roof and livestock and other uses or when they want to cross to drainages. Such activities are absolutely common during dry seasons (November to June) and rainy seasons (July to September) due to generating fresh and healthy grasses. This implies grasses located near trails and drainages seem to have higher susceptibility to overgrazing. Subsequent increment demand of water resources tends to flip back the near yards' grassland to overgrazing and degradation (Fig. 6b, d). Therefore, the predicted probability model suggested that designing a $0.72-\mathrm{km}$ buffer on the accessibilities may likely protect the conversion of grasslands near drainages and trails to overgrazing, because the predicted probability decreases close to 0.01 (Fig. 7b).

\section{Conclusion and implications}

This study gives insight to the processes of determinants of land cover transitions in the main grassland plain of NSNP using GIS, high-resolution satellite imageries, and geo-statistical technique. The results evidently have shown that there have been significant land cover transitions in the study area over past three decades (19862019). Topography-related variables and distance variables coupled with demographic dynamics, conflicts, drought, and successive government policies have determined the land cover transitions in the study area. These determinants resulted in systematic gains, losses, and swap change in location-hence, there have been conversion, degradation, and sometimes restoration of land cover transitions in the study area. The conversions of land cover from woody vegetation-to-grassland and riverine forest-to-woody vegetation, degradation of grassland-to-open-overgrazed land, and restorations of grassland from open-overgrazed land are found to be systematic whereas the rest transitions are experienced either random or partly systematic transitions. However, the massive conversion of woody vegetation initially to grasslands and subsequently grasslands-to-open-overgrazed areas were the most dominant signals of land cover transitions observed in this study. Consequently, overgrazing in the main grassland plain of the NSNP is not the immediate cause for disappearance of woody vegetation. Nevertheless, such conversion may have far-reaching impact on biodiversity loss and land degradation.

The results of this study indicate habitat destruction due to loss of forest, suggesting the livelihood of the entire communities directly engaged in firewood extraction and charcoal production. This requires availing affordable alternative energy source technologies to the communities. Therefore, the stakeholders in collaboration with other concerned organizations should recover the forest loss by planting quick growth and adoptive vegetation in and around the disturbed park. This study also informs that widely observed formal and informal resettlements are surged into the main park which further resulted in massive losses of forest for constructions and urban/market expansions. Therefore, the policymakers should avoid resettlement policy in and around the park and strong follow-up law and measures should be taken on informal resettlement. The spatially explicit statistical modeling indicated that the forest existing in the lower elevation, gentle slopes, and locations near to rivers, trails, and forest edges increases the likelihood of forest-to-grassland conversion. Therefore, this requires urgent biodiversity conservation and management actions on these locations. Hence, the model for predicted probability suggested that a $0.75 \mathrm{~km}$ buffer are most likely to protect forests existing near to drainages, trails, and forest edge from conversion to grassland.

This study also informs that increasing the demand of grasses for fodder, roof construction, and other uses attributed to conversion of grassland-to-open-overgrazed areas. The dislocated pastoralists and agropastoralists due to geo-politics and possibly drought entirely depend on the natural resources of the park. Mass of these pastoralists' livestock and wild animals in the park are computing for fodder on $42.3 \%$ (4434 ha) of the total grassy area. This resulted in continued land degradation due to overgrazing which is beyond the carrying capacity of the grassland and former deforested areas in the main grassland plain of NSNP. The savannah grasses located near drainages, trails, lower elevation, gentle slopes, east, and north facing aspects are likely to be open-overgrazed. Therefore, the identity and boarder commission with concerned bodies should revise and design participatory park border demarcation to avoid recurrent conflicts between Guji I, II, Borena, Gedeo, and Segen peoples. Likewise, the minister of water, mining, and energy together with other organizations should built irrigations and artificial lakes and select suitable pampas in the pastoralist and agro-pastoralist areas. This could make societies more profitable and skip 
the poverty line. Therefore, according to analyzed results constructing a buffer of $0.72 \mathrm{~km}$ can protect the grassland located near the existing drainages and trails from conversion to open-overgrazed area.

Moreover, habitat destruction due to massive conversion of woody vegetation initially to grasslands and subsequently grasslands-to-open-overgrazed land in the NSNP, particularly the main grassland plain, also linked to poor management and conservation policy of EWCA as compared to previous park management enforcement of NSNP under African parks foundation. Therefore, the main grassland plain of NSNP requires urgent biodiversity conservation and strong management policy implementation.

\section{Abbreviations}

GIA: Geospatial Information Agency; GIS: Geographic Information System; LULC: Land use and land cover; NSNP: Nech Sar National Park; ROC: Relative operating characteristic

\section{Acknowledgements}

The author thanks Guji I and II, Borena, Gedeo pastoralists and agropastoralists, and local communities of Arbaminch town who helped during field data collection and provide their views. I like to acknowledge Tesfaye Gebeyehu (Associte Proff.) for language editorial works. I also thank the three anonymous reviewers and editor in the journal of Ecological Processes for their constructive comments. The author is also greatly indebted to thank the ESA for offering free access to Sentinel-2 image.

\section{Author's contributions}

$\mathrm{KT}$ has designed the study, collected all data, carried out field work, analyzed satellite imageries, and interpreted the document of the manuscript. Moreover, KT has contributed all literature work, reviewing, and editorial works. Therefore, KT is the only author of this manuscript. The author read and approved the final manuscript.

\section{Funding}

Not applicable

\section{Availability of data and materials}

All data are included in the manuscript.

\section{Ethics approval and consent to participate}

Not applicable.

\section{Consent for publication}

Not applicable

\section{Competing interests}

The author declares that he has no competing interests.

Received: 6 June 2019 Accepted: 15 October 2019

Published online: 09 December 2019

\section{References}

Alo CA, Pontius RG Jr (2008) Identifying systematic land-cover transitions using remote sensing and GIS: the fate of forest inside and outside protected areas of southwestern Ghana. Environ Plan B Plann Design 35(2):280-295. https:// doi.org/10.1068/b32091

Andabo WG, Gamo FW (2015) Land use practices, woody plant species diversity and associated impacts in Maze National Park, Gamo Gofa Zone, Southwest Ethiopia. Plant 3(6):64-74. https://doi.org/10.11648/j.plant.20150306.12

Anderson BJ, Hardy EE, Roach JT, Witmer RE (1976) A land use and land cover classification scheme for use with remote sensor data. Development 2005:28. https://doi.org/10.3133/pp964

Arjjumend H, Shibata S, Fakana ST (2018) Ecosystem services of forest ecosystem in Nech Sar National Park, Ethiopia: identifying the challenges and conservation measures. J Glob Resour 4(02):18-29
Belay S, Amsalu A, Abebe E (2014) Land use and land cover changes in Awash National Park, Ethiopia: impact of decentralization on the use and management of resources. Open J Ecol 4:950-960. https://doi.org/10.4236/ oje.2014.415079

Biazin B, Sterk G (2013) Drought vulnerability drives land-use and land-cover changes in the rift valley dry lands of Ethiopia. Agric Ecosyst Environ 164 100-113

Bolton M (1973) Hartebeest in Ethiopia. Oryx 12:99-108

Braimoh A (2006) Random and systematic land-cover transitions in northern Ghana. Agric Ecosyst Environ 113(1-4):254-263. https://doi.org/10.1016/j. agee.2005.10.019

Congalton RG, Green K (2009) Assessing the accuracy of remotely sensed data: principles and practices, 2nd edn. CRS Press, Baco Ratton

Deribew KT, Dalacho DW (2019) Land use and forest cover dynamics in the North-Eastern Addis Ababa, central highlands of Ethiopia. Environ Sys Res 8 : 1-18. https://doi.org/10.1186/s40068-019-0137-1

Duckworth JW, Evans MI, Safford RJ, Telfer MG, Timmins RJ, Zewdie C (1992) A survey of Nech Sar National Park, Ethiopia: report of the Cambridge Ethiopia ground-water forest expedition 1990. International council for bird preservation study report No. 50, UK

FAO (2010) Global forest resource assessments. Forestery Paper 163, Rome

Fetene A, Hilker T, Yeshitela K, Prasse R, Cohen W, Yang Z (2016) Detecting trends in landuse and landcover change of Nech Sar National Park, Ethiopia. Environ Manag 57:137-157. https://doi.org/10.1007/s00267-015-0603-0

Hailemariam SN, Soromessa T, Teketay D (2016) Land use and land cover change in the Bale Mountain Eco-Region of Ethiopia during 1985 to 2015. Land 5:41. https://doi.org/10.3390/land5040041

Hosemer DW, Lemeshow S (2000) Applied logistic regression. Wiley, New York

Hung M, Wu Y (2005) Mapping and visualizing the Great Salt Lake landscape dynamics using multi-temporal satellite images, 1972-1996. Int J Remote Sens 26:1815-1834. https://doi.org/10.1080/01431 16042000298324

Jacobs MJ, Schroeder A (1997) Awash National Park Management Plan. EWCO, Addis Ababa

Jensen J (1996) Introductory to digital image processing: a remote sensing perspective. Prentice Hall, Upper Saddle River

Lambin EF, Geist HJ, Lepers E (2003) Dynamics of land-use and land-cover change in tropical regions. Ann Rev Environ Resour 28:205-241

Landis JR, Koch GG (1977) The measurement of observer agreement for categorical data. Biometrics 33(1):159-174. https://doi.org/10.2307/2529310

Lillesand TM, Kiefer RW, Chipman J (2008) Remote sensing and image interpretation, 6th edn. Wiley and Sons Inc, New York

Lohnert B (2017) Migration and the rural-urban transitions in sub-Saharan Africa Centre for Rural Development (SLE), Berlin, pp 1-78

Mamo Y, Mengesha G, Fetene A, Shale K, Girma M (2012) Status of the Swayne's hartebeest (Alcelaphus buselaphus swaynei) meta-population under land cover changes in Ethiopian protected areas. Int J Biodivers Conserv 4:416426. https://doi.org/10.5897/JJBC12.024

Menale W, Schneider W, Assefa MM, Demele T (2011) Spatial and temporal land cover changes in the Simen Mountains National Park, a world heritage site in northwestern Ethiopia. Remote Sens 3:752-766. https://doi.org/10.3390/ rs3040752

Mondal I, Srivastava VK, Roy PS, Talukdar G (2014) Using logit model to identify the drivers of landuse landcover change in the lower Gangetic basin, India. Int Arch Photogramm Remote Sens Spatial Inf Sci 11(8):853-859

National Metrology Agency (NMA) (2013) Climate data set and information, Addis Ababa

Ouedraogo I, Barron J, Tumbo SD, Kahimba FC (2016) Land cover transition in northern Tanzania. Land Degrad Develop 27:682-692. https://doi.org/10. 1002/ldr.2461

Pontius R (2004) Detecting important categorical land changes while accounting for persistence. Agric Ecosyst Environ 101:251-268. https://doi.org/10.1016/j. agee.2003.09.008

Puyravaud J (2003) Standardizing the classification of the annual rate of deforestation. Forest Ecol Manag 177(1):593-596. https://doi.org/10.1016/ S0378-1127(02)00335-3

Rahmato D (2009) The peasant and the state: studies in agrarian change in Ethiopia since 1950s-2000s. Addis Ababa University, Addis Ababa

Regassa R, Yirga S (2013) Distribution, abundance and population status of Burchell's zebra (Equus quagga) in Yabello wildlife sanctuary, southern Ethiopia. J Ecol Nat Environ 5(3):40-49. https://doi.org/10.5897/ JENE2012.0352 
Sivalek B (2008) Use of GIS technologies in biodiversity conservation: case study of vegetation and soil mapping in Nech Sar National Park, Ethiopia. MSc. Thesis, Czech Univrsity of Life Science, Parague

Syombua M (2013) Land use and land cover change and their implications for human-wildlife conflicts in the semi-arid rangelands of southern Kenya. J Geogr Reg Plann 6(5):193-199. https://doi.org/10.5897/JGRP2013.0365

Teferi E, Uhlenbrook S, Wenniger J (2013) Understanding recent land use and land cover dynamics in the source region of the Upper Blue Nile, Ethiopia: spatially explicit statistical modeling of systematic transitions. Agric Ecosys Environ 165:98-117. https://doi.org/10.1016/j.agee.2012.11.007

Temesgen F, Bikila W (2018) Biodiversity status \& conservation challenges of protected areas of Ethiopia: Awash \& Nech Sar National Parks in focus. J Nat Sci Res 8(5):46-57

Veldkamp A, Lambin EF (2001) Predicting land-use change. Agric Ecosys Environ 85:1-6

Verburg PH, Schot PP, Dijst M, Veldkamp A (2004) Land use change modelling: current practices and research priorities. GeoJournal 61(4):309-324. https:// doi.org/10.1007/s10708-004-4946

Verburg PH, Veldkamp A (2001) The role of spatially explicit models in land-use change research: a case study for cropping pattern in China. Agric Ecosys Environ 85:177-190

Wolde Yohannes A, Cotter M, Kelboro G, Desalegn W (2018) Land use and land cover changes and their effects on the landscape of Abaya-Chamo Basin, southern Ethiopia. Land 7:2. https://doi.org/10.3390/land7010002

Yohannes H, Mohammed A, Elias E (2017) Land use/land cover dynamics and its impact on biodiversity resources in the Abijata Shalla National Park, Central Rift Valley Lakes Region, Ethiopia. Environ Sci Ind J 13(5):152

Yuan F, Sawaye KE, Loeffeljolz BC, Bauer ME (2005) Land cover classification and change analysis of the twin cities (Minnesota) metropolitan area by multitemporal Landsat remote sensing. Remote Sens Environ 98(3):327-328. https://doi.org/10.1016/j.rse.2005.08.006

Yusuf H, Treydte AC, Demissew S, Woldu Z (2011) Assessment of woody species encroachment in the grasslands of Nechi Sar National Park, Ethiopia. Afr J Ecol 49:397-409

Zeleke G, Hurni H (2001) Implications of land use and land cover dynamics for mountain resource degradation in Northwestern Ethiopia highlands. Mt Res Dev 21:184-191. https://doi.org/10.1659/0276-4741(2001)021[0184: IOLUAL]2.0.CO;2

Zerga B (2015) Awash National Park: its degradation status and protection measures. Palgo J Agrc 2(3):57-66 http://www.palgojournals.org/PJA/Index.htm

\section{Publisher's Note}

Springer Nature remains neutral with regard to jurisdictional claims in published maps and institutional affiliations.

\section{Submit your manuscript to a SpringerOpen ${ }^{\circ}$ journal and benefit from:}

- Convenient online submission

- Rigorous peer review

- Open access: articles freely available online

- High visibility within the field

- Retaining the copyright to your article

Submit your next manuscript at $\boldsymbol{\nabla}$ springeropen.com 